\title{
ПРОЯВЛЕНИЕ ЗАКОНА ПОЛИМЕРИЗАЦИИ/ОЛИГОМЕРИЗАЦИИ НА НИЗШИХ УРОВНЯХ РАЗВИТИЯ ЖИВОЙ МАТЕРИИ

\author{
В.И. Михалевич
}

Зоологический институт РАН, Санкт-Петербург

Эл.nочта:mikha07@mail.ru

Статья поступила в редакичию 27.03.2016; принята к печати 02.11.2016

В 20-х - 50-х гг. XX в. В.А. Догелем был открыт и обоснован принцип полимеризации/ олигомеризации на клеточном уровне организации материи и прослежено его действие у одноклеточных и многоклеточных эукариот, в основном беспозвоночных. В данной статье показано, что действие этого принципа проявляется не только у эукариот, но и у прокариот. В.А. Догель также изучил и показал преимущественное проявление полимеризации по сравнению с олигомеризацией у одноклеточных. В данной статье показано также, что сходным образом полимеризация преобладает и у вирусов и бактерий как первый необходиый этап прогрессивных эволюционных преобразований. Более того, принцип полимеризации является основой перехода с одного уровня организации на другой, более высокий. Таким образом, открытый В.А. Догелем принцип можно считать одним из основных законов прогрессивной эволюции живых систем.

Ключевые слова: эволюция, полимеризация, олигомеризация, дифференцииции, одноклеточные эукариоты, прокариоты.

\author{
THE POLYMERIZATION/OLIGOMERIZATION LAW \\ AS MANIFESTED AT THE LOWER LEVELS OF DEVELOPMENT OF THE \\ LIVING MATTER \\ V.I. Mikhalevich \\ Zoological Institute of the Russian Academy of Sciences, Saint Petersburg, Russia \\ E-mail: mikha07@mail.ru
}

The principle of polymerization/oligomerization was formulated by V.A. Dogel and in 1920ies, and its manifestations were being traced by him in unicellular eukaryotes and, mainly, invertebrate metazoans untill 1950ies. In the present paper, it is shown that this principle is also applicable to prokaryotes. V.A. Dogel has also shown that, in unicellulates, polymerization dominates over oligomerization. In the present paper, it is shown that this is also true for viruses and bacteria. Morover, the principle of polymerization is at the base of transitions from lower to higher levels of organization of the living matter. Thus, the principle formulated by V.A. Dogel may be regarded as one of the main laws the progressive evolution.

Keywords: evolution, polymerization, oligomerization, differentiation, unicellular eukariotes, procaryotes.

\section{Введение}

Работа Валентина Александровича Догеля, в которой он впервые сформулировал и обосновал принцип полимеризации структур организма и ее ведущей роли в эволюции протистов, вышла в 1929 г. [60]. Эта публикация была почти не замечена научной общественностью. Валентин Александрович продолжал исследования в этом направлении.

В дальнейших работах В.А. Догель сформулировал также сущность понятия олигомеризации, рассматривая не только простейших, но и многоклеточных. Он выявил и проследил проявление общих закономерностей полимеризации/олигомеризации на многочисленных примерах изменений числа и строения гомологичных и гомодинамных органелл и органов и их роль в эволюции различных групп: Protozoa и Metazoa [11-15]. Ряд отечественных биологов (В.Н. Беклемишев [2], Л.А. Зенкевич [99], А.А. Захваткин [18] и другие) с интересом восприняли его идеи. Специалисты почти по каждой группе животных старались проследить проявление этих закономерностей на изучаемых ими организмах, о чем свидетельствует большое число работ в этой области на русском языке, особенно в области зоологии $[1,3,9$,
$10,17,18,25,48]$. Появился интерес к этой проблеме и у ботаников $[16,27,28,53,57]$ и микологов [20]. Законы эволюции, в том числе закон В.А. Догеля о полимеризации и олигомеризации, включены в программы биологических факультетов вузов России. Так, в ЛГУ студентам, изучающим беспозвоночных, А.И. Гранович читает курс лекций «Дискуссионные вопросы теории эволющии».

На Западе все эти работы и идеи до сих пор остаются практически не замеченными.

Число публикаций о полимеризации/олигомеризации на русском языке особенно возросло после опубликования В.А. Догелем в 1954 г. монографии «Олигомеризация гомологичных органов» [14]. К опубликованию этой книги его побудило недостаточное внимание специалистов к ранее опубликованным им идеям. В предисловии к книге он писал: «Наши взгляды не получили еще всеобегг признания, что мы приписываем тому, что опубликованные нами по этому поводу работы носили характер небольших журнальных статей, по необходимости сильно ограниченных в размерах и потому, может быть, недостаточно убедительных и доходчивых». 
Книга включила в себя более 400 примеров полимеризованных и олигомеризованных систем животных, относящихся (по классификации того времени) к 38 классам Metazoa ${ }^{1}$. Очевидно, не только объем материала, но и само обращение к многоклеточным животным, обладающим более сложными структурами и более известных зоологам, также сыграло свою роль в признании его идей в широком кругу российских биологов, о чем свидетельствует огромное число последующих работ, рассматривающих процессы олигомеризации/полимеризации на примере многоклеточных. Более просто устроенные группы (простейшие, бактерии, вирусы) оставались почти не затронутыми такими исследованиями. Именно поэтому в данной статье внимание сосредоточено на них. Бактерии и вирусы с этой точки зрения вообще не рассматривались. Это стало возможным благодаря новым данным, полученным с помощью электронной микроскопии.

Выводы, полученные В.А. Догелем ранее, были основаны на его собственных скрупулезных исследованиях сложно устроенных инфузорий из желудка жвачных (отряд Entodiniomorpha, семейства Ophryoscolecidae и Cycloposthiidae), филогения которых была достаточно хорошо прослежена, и жгутиконосцев из желудка термитов, принадлежащих отрядам Polymastigina и Hypermastigina, а также с привлечением немногих известных в то время данных по другим группам Protista. И до сих пор в отношении одноклеточных эукариот процессы проявления у них полимеризации/олигомеризации остаются наиболее слабо исследованными. Можно упомянуть лишь несколько работ Ю.И. Полянского [39], Ю.И. Полянского и И.Б. Райкова $[40,41,42]$, блестящие монографии И.Б. Райкова [44, 45] и Д.В. Осипова [36], уделивших внимание полимеризации/олигомеризации ядер инфузорий, небольшую статью М.Г. Петрушевской по радиоляриям [37] и несколько работ по фораминиферам Н.И. Маслаковой [26], Н.И. Субботиной [49], В.И. Михалевич $[32,80,81]$. Между тем, многие одноклеточные устроены достаточно сложно, иногда достигая поразительной для их уровня сложности, а электронно-микроскопические исследования дали возможность их углубленного изучения и обнаружения новых структур. Поэтому в настоящей статье особое внимание уделено одноклеточным эукариотам, и среди них - фораминиферам, являющимся предметом моего специального изучения.

В.А. Догель заметил, что «удовлетворяющая потребности организма деятельность любой системы зависит не только от типа строения органов-компонентов, от их величины и т. д., то есть от качества органов, характеризующих систему, но и от их числа» [12]. Он

${ }^{1}$ Вследствие применения новых методов исследования, как электронно-микроскопических, так и молекулярных, системы организмов, особенно более просто устроенных одноклеточных эукариот, претерпели за последние десятилетия глубокую перестройку. Поскольку полная ревизия на новом уровне исследований для большинства групп еше не завершена, в данной работе систематическая принадлежность упоминаемых организмов дается по цитируемому автору и лишь в некоторых случаях уточняется по новейшим данным. Под протистами в настоящее время понимают преимущественно одноклеточных эукариот, которые в строгом смысле не являются четко отграниченным от других царств таксоном. Единого кодекса номенклатуры для всех эукариот пока нет, и название Protista на сегодняшний день можно рассматривать как временное и компромиссное. Недостаточная изученность всего массива прежних данных на новом уровне исследований и несопоставимость прежних и новых данных привели к появлению безранговой классификации, основанной на молекулярногенетических данных. не только открыл и ясно сформулировал суть явлений полимеризации/олигомеризации, но и показал их взаимосвязь, их физиологическое и эволюционное значение, их исключительную роль в дальнейшем прогрессивном развитии эукариотических организмов. Он дал в руки морфологов мощное орудие сравнительного анализа, которое помогает правильно определить направление этого развития. Именно сравнительно-морфологический и филогенетический анализ, основанный на догелевских идеях, позволил автору настоящей статьи вернее понять и оценить эволюцию фораминифер, фундаментально перестроить их прежнюю систему [29-34, 78-82]. В настоящее время эта новая система получила подтверждение на молекулярно-генетическом уровне исследований [84, 89].

Работы Валентина Александровича не только ведут читателя дорогой мысли и учат мысли и пристальному вниманию к фактам, но и одновременно доставляют эстетическое удовольствие благодаря своей образной и точной лексике, блестящей логике и прекрасному русскому языку.

Открытую им закономерность В.А. Догель скромно называл «принципом, правилом»: «Как олигомеризация, так и полимеризация представляют собой биологические правила, а не законы» [12].

Вместе с тем, явления полимеризации/олигомеризации можно рассматривать как проявления целого ряда аспектов эволюции, таких как: 1) принцип полимеризации/олигомеризации и дифференциации при наличии разрешающих условий и обратных связей (В.А. Догель); 2) принцип последовательного возрастания сложности организмов (включая возникновение и усложнение интегрирующих систем внутри организма); 3) принципы прогрессирующей специализации (Ш. Депере); 4) принцип параллелизмов и конвергенции; 5) закон необратимости эволюции (принцип Долло); 6) принцип происхождения от неспециализированных предков (принцип Копа); 7) принцип адаптивной радиации (принцип Ковалевского-Осборна); 8) блок-модульный принцип (современный термин для принципа Шмальгаузена, называвшегося ранее принципом интеграции, подразумевавшим включение эволюционных достижений предшествующих групп); 9) ароморфоз и идиоадаптации, филэмбриогенез (Северцова); 10) принцип смены фаз (Северцов-Шмальгаузен); 11) чередование темпов эволюции (Дж. Симпсон).

Усилия автора будут направлены на то, чтобы показать более широкий характер закона полимеризации/олигомеризации, действующего на всех ступенях развития биологической материи - не только клеточного, но и доклеточного уровня.

\section{ЧЕРТЫ СТРОЕНИЯ И ПРОЦЕССЫ ПОЛИМЕРИЗАЦИИ/ ОЛИГОМЕРИЗАЦИИ ОДНОКЛЕТОЧНЫХ ЕUКАRYОТА}

\section{Понятие полимеризации по В.А. Догелю}

Как упоминалось ранее, процессы полимеризации/ олигомеризации среди эукариот оказались наименее изученными на одноклеточном уровне, хотя именно при изучении этих организмов и их органелл В.А. Догель сформулировал эти понятия впервые [60]. Позже $[11,12,14]$ он распространил их и проследил эти 
закономерности и их изменения в процессе эволюции на органах многоклеточных (Metazoa).

Одноклеточный уровень организации имеет свои глубокие особенности, так как клетка существует самостоятельно, обладает своей собственной индивидуальностью и более высокой степенью свободы, не будучи подчинена целостным централизованным системам многоклеточного организма.

В.А. Догель понимал под термином полимеризации «...развитие у особи простейших многих гомологичных и равноценных органоидов» и, «вместе с тем, выполняющих одну и ту же функцию» [12]. Он также показал, что гомодинамные органеллы (и органы), то есть образования, выполняющие одну и ту же функцию, могут иметь различное строение и происхождение, и что в процессе эволюции вырабатывается такое количество полимеризованных структур клетки (а затем - и многоклеточного организма), которое оптимально для выполнения той или иной функции. Первыми объектами исследования он выбрал наиболее сложно устроенных и эволюционно продвинутых протистов (инфузорий и жгутиконосцев), «...филогения которых достаточно хорошо прослежена», и потому «...характер направленности происходящих в данной группе морфологических изменений не подлежит сомнению» [12].

Представляется уместным в статье, посвященной учению Валентина Александровича, повторить один из наиболее ярких и наглядных приведенных им примеров [11] полимеризации органелл и целых их комплексов у жгутиконосцев из отряда Polymastigina (рис. 1), исходным родом которого считался род Bodo с одним ядром и простым маленьким парабазальным тельцем (рис. 2, 5). У Proboscidiella multinucleata (рис. 1,1 ) в результате не доведенного до конца процесса деления образовалось три триады жгутиков и 3 аксостиля, ядро же сохранилось в единственном числе. Кроме этого, В.А. Догель описывает и другой способ «умножения органоидов в пределах одной общей плазматической территории»: у $P$. multinucleata могут умножаться в числе не только двигательные органеллы, но также и ядра, в результате чего возникает многоядерная форма с несколькими венчиками триад жгутиков, названная им «сомателлой» (рис. 1,2$)^{2}$. На том же рисунке он приводит также один из видов Calonympha grassii из того же отряда, у которого полимеризация зашла еще дальше (рис. 1, 3). Его особи на переднем конце клетки несут несколько венчиков жгутиковых триад разного строения: одни из них включают обычный набор органелл кинетиды («рабочей единицы» жгутиковых, который состоит из тетрады жгутиков, базального зерна, парабазального тела, ядра и аксостиля [12]). Этот полный набор называют кариомастигонтом. Другие венчики жгутиков расположены на самой вершине клетки, ее теменном конце и отличаются от первых лишь отсутствием ядра - это акариомастигонты. Осевые палочки (аксостили) и тех, и других наборов собраны в один общий пучок. На этом и других примерах Валентин Александрович показал, что «умножение числа двигательных аппаратов и парабазальных тел» (добавим - и ядер) «может идти у Polymastigina разными темпами».

Этот термин сохранил в своих работах и А.А. Захваткин [17]. Позднее Л.Н. Серавин и А.В. Гудков [47] приписали его происхождение Н.И. Ширкиной [9].
Этот ставший уже классическим пример наряду со многими другими помог В.А. Догелю понять «скрытый смысл» процессов полимеризации, направленный не на размножение, а на усиление функций. Поэтому парабазальное тело, представляющее скопление запасного вещества, необходимого для работы жгутиков, у полимеризованных кинетид увеличивается и в размере, и в числе. У одних, как у Bodo, это маленькое тельце, у других несколько, иногда целый венчик крупных тел, палочковидных, колбасовидных или иной формы [12] (рис. 3-5]. Это наблюдение В.А. Догеля очень важно для понимания процессов эволюции. Позже В.М. Корецкий [23] подчеркнул роль избыточности как необходимой характеристики в эволюционных процессах.

Проанализировав множество примеров, В.А. Догель пришел к выводу, что число опорно-двигательных аппаратов может увеличиваться у жгутиковых по-разному, но чаще всего образуются триадные и, еще чаще, тетрадные варианты $(4,8,16,32)$. Интересно, что позже при изучении полимеризации числа щупалец у медуз и других кишечнополостных [14] им также было отмечено преобладание триадных и, особенно, тетрадных вариантов. Кратное 2-м и 4-м увеличение компонентов внутри структур известно и на молекулярном и генном уровне, и было бы интересно подробнее изучить и обобщить эти наблюдения. В.А. Догеля иногда упрекали, что название найденной им закономерности он неудачно взял из химии, что полимеризация в органических молекулах принципиально отличается от таковой биологических организмов. Между тем, принцип развития и усложнения структуры через первую предшествующую остальным изменениям стадию полимеризации путем умножения подобных структурных единиц является универсальным правилом, и, отличаясь на каждом структурном уровне специфическими особенностями, в основе своей один и тот же. Использованное В.А. Догелем название как раз продумано и удачно (отражает самую суть явления). Число миофрисков, обеспечивающих расширение и сокращение тела и удельного веса изменением натяжения скелетных радиальных игол у разных родов Acantharia также увеличивается от 2-4 до 6-8, 16-32, 40-60 [92]. По-видимому, дупликации и тетрадные варианты чаще бывают оптимальны для усиления функциональной активности. Вариант 5-кратного увеличения встречается гораздо реже (например, у Pentatrichomonas).

Важными теоретическими выводами В.А. Догеля было не только то, что в разных системах органелл (и органов) полимеризация может идти разными темпами, но также его предположение о том, что полимеризация может возникать в результате не доведенного до конца деления при подавлении процесса бесполого размножения. Он проиллюстрировал это на примере рода Giardia (= лямблии) (Polymastigina, Diplomonadida), у которой не только 4 жгута, но и ядро и аксостиль удваиваются, и при этом оба комплекса располагаются билатерально симметрично, «зеркально отображая друг друга» [12, рис. 13] (рис. 4, 6 данной работы). По этой же осевой линии, разделяющей две половины, происходит и процесс деления. В других случаях полимеризация может не иметь никакого отношения к бесполому размножению и осуществляться в виде множественной за- 

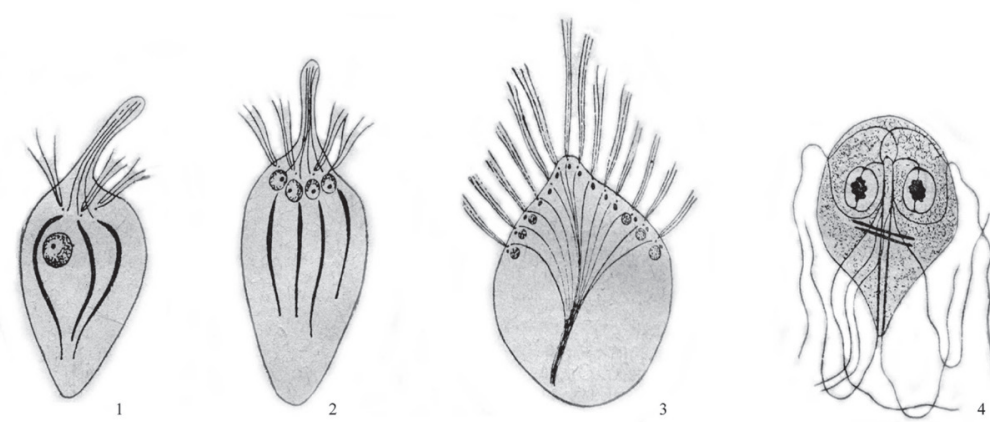

Рис. 1. Полимеризация жгутиков, опорно-двигательных аппаратов и ядер жгутиконосцев:

1 - Proboscidiella multinucleata Kof. A. Awezy (Polymastigina): особь с одним ядром и тремя наборами опорно-двигательных аппаратов (три триады жгутиков и три аксостиля); 2 - Proboscidiella multinucleata Kof. A. Awezy (Polymastigina): особь c многими ядрами и наборами опорно-двигательных аппаратов; 3 - Calonympha grassii A. Foa (Polymastigina) с тремя венчиками кариомастигонтов и несколькими вышележащими венчиками акариомастигонтов, внутри тела соответственные аксостили (по [76]); 4 - жгутиконосец Giardia caviae Heg. (Polymastigina): видно симметричное расположение удвоенного числа ядер, аксостилей (2), жгутиков (8) и резервных запасов (две косо расположенные палочки)
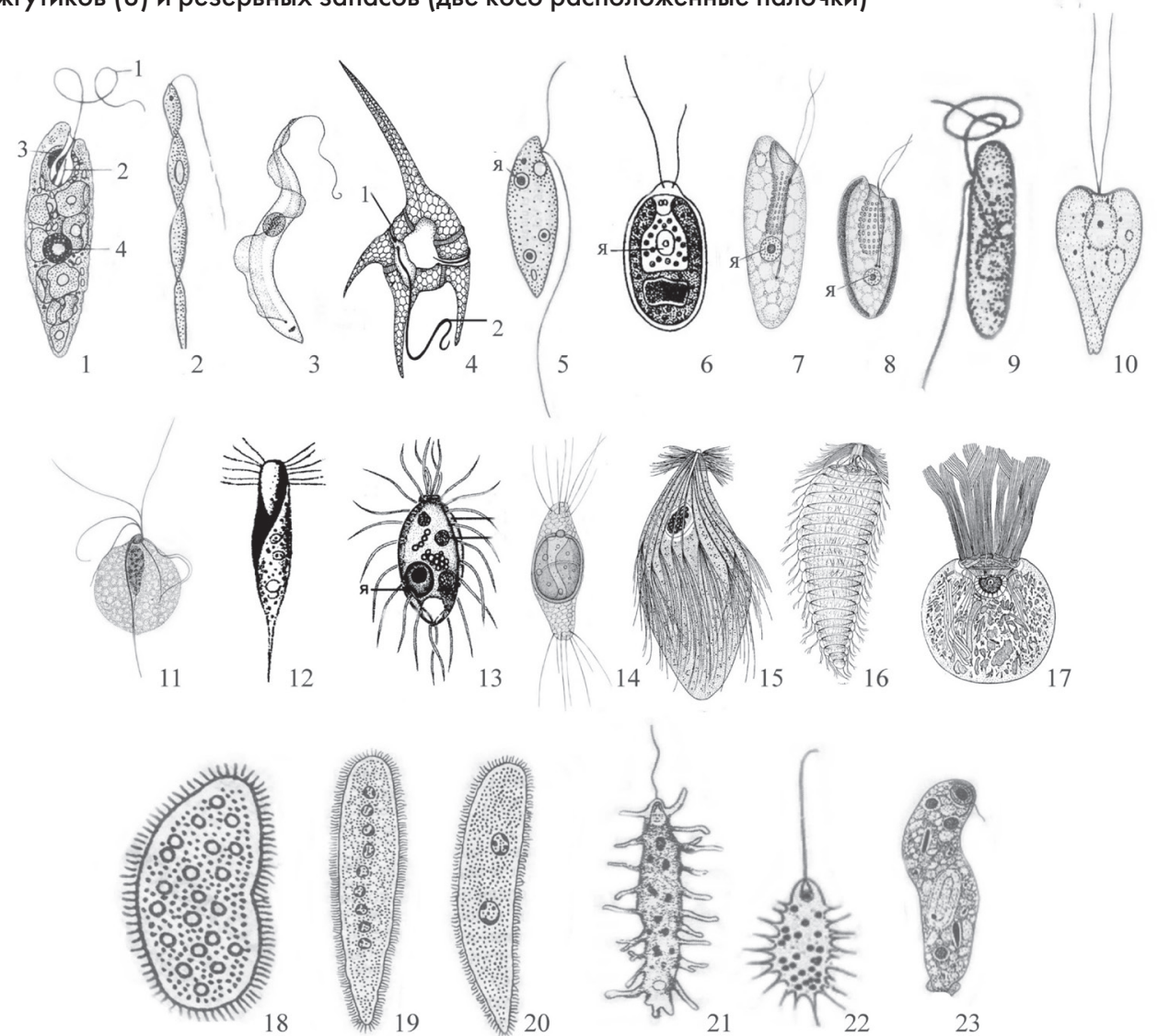

Рис. 2. Число жгутиков у различных представителей жгутиковых и опалинат:

1-10: двужгутиковые и одножгутиковые формы, второй жгутик может быть коротким и находиться в кармане. 1 - Euglena gracilis (Euglenoidina) (по [50]): 1 - длинный жгутик, 2 - короткий жгутик, 3 - глазок (стигма), 4 - ядро; 2 - Phyłomonas sp. (Trypanosomatidae, Kinetoplastidea, Euglenozoa) (nо [54]); 3 - Trypanosoma sp. (Trypanosomatidae, Kinetoplastidea, Euglenozoa); 4 - Ceratium hirudinella (Dinoflagellata, Ceratiineae): 1 - короткий жгутик в бороздке между двумя частями раковины, 2 - задний жгутик;

5 - Bodo saltans (Euglenozoa, Kinetoplastidea) [50]; 6 - Chlamidomonas angulosum (Chlorophyta) (no [69]); 7 - Chilomonas paramecium (Cryptomonadina) (no [69]); 8 - C. ovatum (Cryptomonadina) ([69]); 9 - Kathablepharis hyalurus (Kathablepharida) (nо Skuja, 1939); 10 - Gyromytus dismonatus (Thaunatomonadina) (nо [22]);

11-19: формы с увеличенным числом жгутиков. 11 - Trichomonas vaginalis (Polymastigota,Trichomonadida) (nо [69]); 12 Spironema multiciliatum (Hemimastigophora) (nо [74, 22]); 13 - Hemimastix amphikineta (Hemimastigophora) (nо [67, 22$] ; 14-$ Malomonas cylindricus (Chrysophyta) (nо [69]); 15 - Leptospironympha sp. (Spirotrichosomidae, Parabasalia) (nо [69]); 16 - Teratonympha sp. (по [69]); 17 - Kofoidia loriculata (Cristamonadea) (по [15]), пучки жгутиков соединены в лорикулы; 18 - Ораlina ranarum; 19) Protoopalina axonucleata; 20) P. intestinalis;

18-20: (Opalinata, Opalinida) (по [51]), два ядра либо многочисленные ядра и многочисленные ряды жгутиков, покрывающие всё тело;

21-23: Pelobiontida, формы с редуцированным числом жгутиков: 21 - Mastigamoeba flexuosa (по [95]); 22 - M. viridis (по [94]; 23 - Tricholimax hylae (nо [68]) 

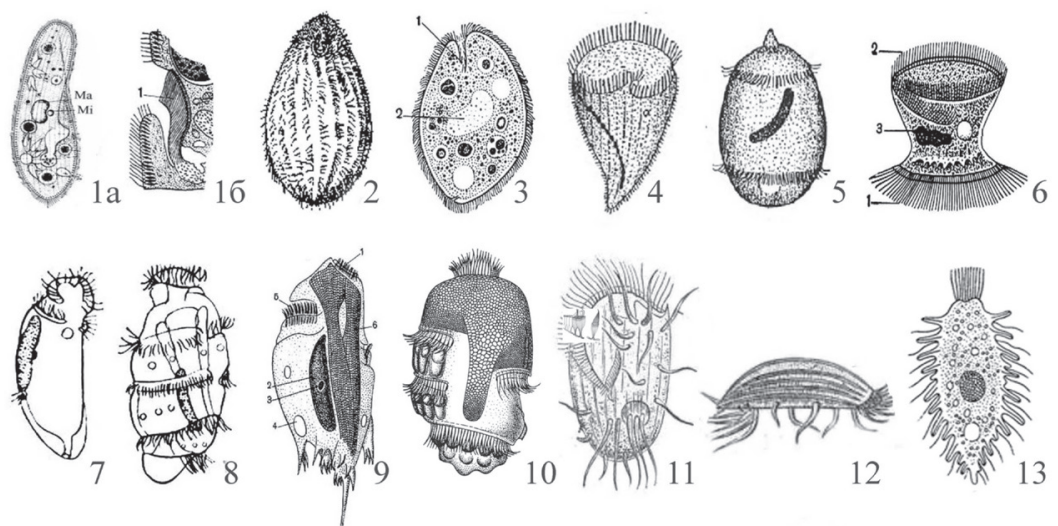

Рис. 3. Олигомеризация и дифференциация ресничек у представителей типа Ciliophora Doflein, 1901:

1 a, 6 - Paramecium caudatum (туфелька) (Holotricha) (по [19]): а - общий вид, б - перистом (глотка) с более мощными ресничками внутри; 2 - Tetrahymena sp. (Spirotrycha) (по [8]); 3 - Balantidium coli (Holotricha) (по [19]): 1 - по краю перистома особые сильноразвитые реснички, 2 - ядро; 4 - Stentor sp. (трубач) (Heterotricha) (по [76]), с околоротовой зоной мембранелл; 5 - Didinium sp. (Litostomatea, Haptorida) (по [76]); 6 - Trichodina pediculus (Peritrichea) (по [19]): 1 - нижний венчик ресничек, 2 - околоротовые реснички, 3 - макронуклеус;

7-9: Ophryoscolecida (7, 8 по [76], 9 по [19]): 7 - Spirodinium confusum; 8 - Polydinium mysoreum из толстой кишки индийского слона; 9 - Ophryoscolex caudatum: 1 - околоротовая ресничная зона, 2 - макронуклеус, 3 - микронуклеус, 4 - сократительная вакуоль, 5 - спинная ресничная зона, 6 - скелетные пластинки;

10 - Troglodytella gorillae (Enthodiniomorpha) (по [19], из кишечника гориллы, околоротовая зона цирр на переднем конце и три зоны цирр, кольцеобразно охватывающих тело; 11 - Euplotes harpa (Spirotrichea); 12 - E. charon. (7-10: Ophryoscolecidae; 11-12: Hypotrichacea) (11, 12 по [76]);

13 - Dactytochiamis sp. (Holotricha, Gymnostomata) (по [15]), сочетание рядов ресничек и стрекательных щупалец

кладки органелл (или органов), как было показано им ранее на примере Proboscidiella и инфузорий из кишечника жвачных. В.А. Догель также обозначил два пути полимеризации: 1) путем новообразований и 2) путем разделения первоначально имевшихся зачатков. Позже С.А. Подлипаев с соавторами [38] назвали первый из этих путей дополнительной полимеризацией, а второй - фиссацией.

Третьим путем полимеризации В.А. Догель считал увеличение размеров органелл или общих размеров тела протистов. Он считал, что «этот способ интенсификации функций осуществляется сравнительно редко» [12].

Важнейшей заслугой В.А. Догеля является то, что, проследив различные проявления полимеризации на примере расположения родов в нескольких филогенетических линиях, он дал биологическое объяснение полимеризации как преимущественного пути эволюционных усложнений у Protozoa, ведущих в то же время к децентрализации и к дезинтеграции усложняющегося организма и предшествующих последующей олигомеризации, понял ее огромное теоретическое значение в вопросе происхождения многоклеточных.

\section{ПОЛИМЕРИЗАЦИЯ МОРФОЛОГИЧЕСКИХ СТРУКТУР РАЗНЫХ ГРУПП ОДНОКЛЕТОЧНЫХ EUKARYOTA}

\section{Полимеризация двигательных органелл} разных групп одноклеточных Eukaryota

Примеры полимеризации различных органелл одноклеточных эукариот, приведенные В.А. Догелем, можно многократно умножить: полимеризуются не только жгутики, реснички и целые кинетиды, но также ядра и внутриядерные геномы, вакуоли, хроматофоры, пиреноиды, митохондрии, стигмы у зеленых жгутиконосцев, число прикрепительных крючков у паразитических инфузорий, скелетные элементы в группах, обладающих органическим или минеральным скелетом, изредка части тела. Нередко встречается и увеличение размеров тела или отдельных органелл, которые В.А. Догель рассматривал как частный случай полимеризации. На примере семейства Ophryoscolecidae B.А. Догель продемонстрировал возрастание у его представителей в ходе эволюции числа скелетных пластинок, сократительных вакуолей, хвостовых шипов и ресничных дуг [12]. На рис. 2 приведены различные примеры увеличения числа жгутиков у жгутиконосцев (рис. 2, 1-17) и опалин (рис. 2, 18-20). Жгутики последних долгое время принимали за ресничный аппарат и относили их к инфузориям. Однако по новым данным [58] их рассматривают как самостоятельный класс Opalinata, их родство с инфузориями опровергается, строение их ядерного аппарата и особенности полового процесса коренным образом отличаются от таковых у Ciliophora. Изначальным считается наличие у жгутиконосцев двух жгутиков разной длины, один из которых считается рулевым, как, например, у Bodo, Chlamidomonas, Gyromitus и других (рис. 2, 5-10). Нередко один из жгутиков сильно укорочен и как бы спрятан в кармане (у Euglena - рис. 2, 1, у зеленых панцирных жгутиконосцев (Dinoflagellata), например у Ceratus, необычные шипы которого помогают этому планктонному виду сохранять плавучесть. рис. 2, 4). Кстати, динофлагелляты - единственные фотосинтезирующие протисты, способные к биолюминесценции, например, широко известная ночесвет- 


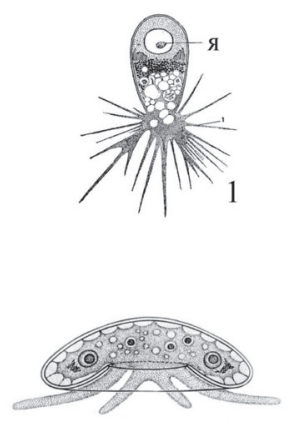

5
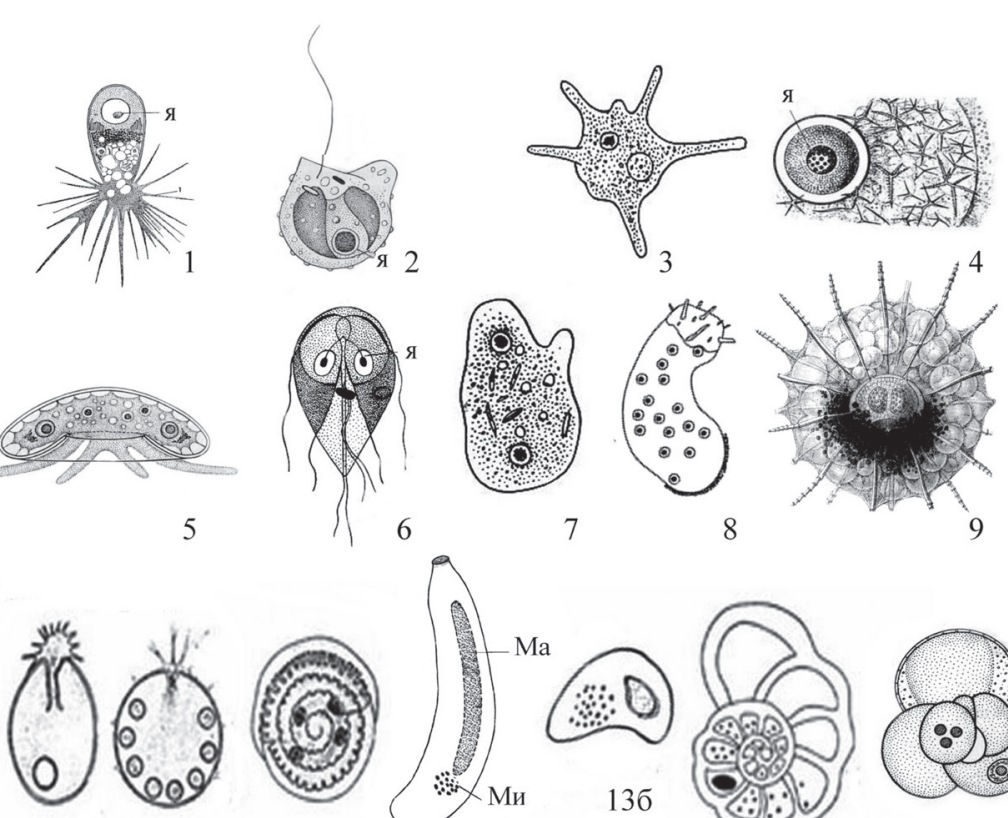

10

11
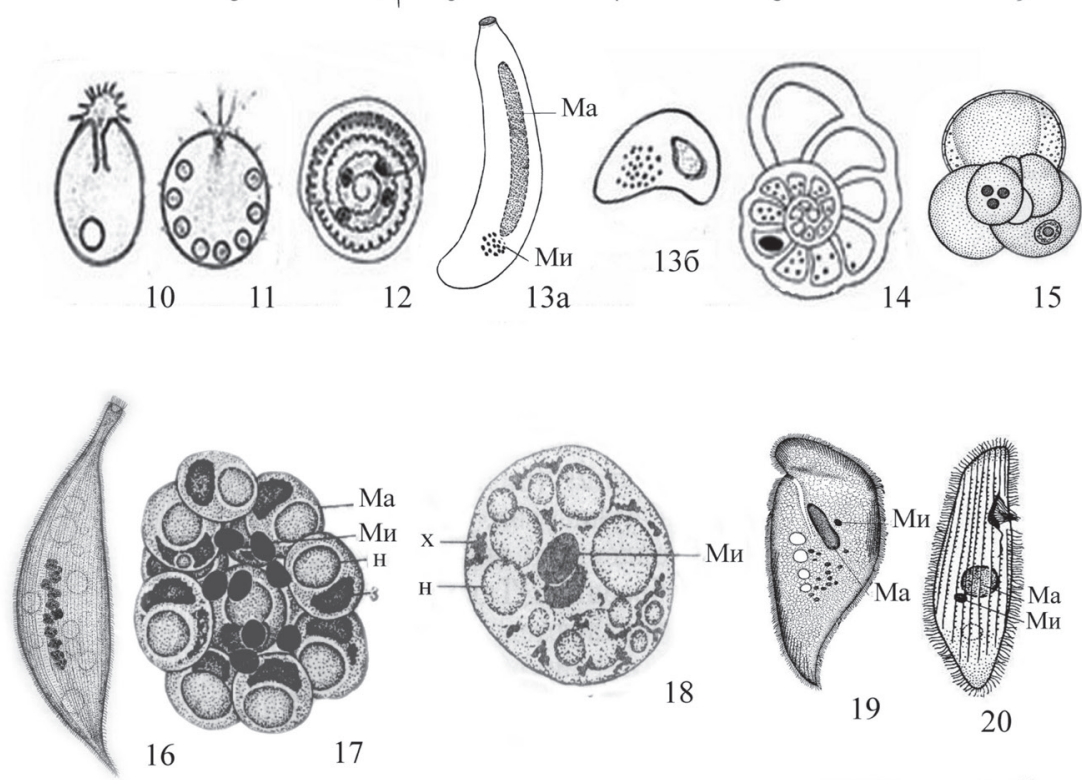

20
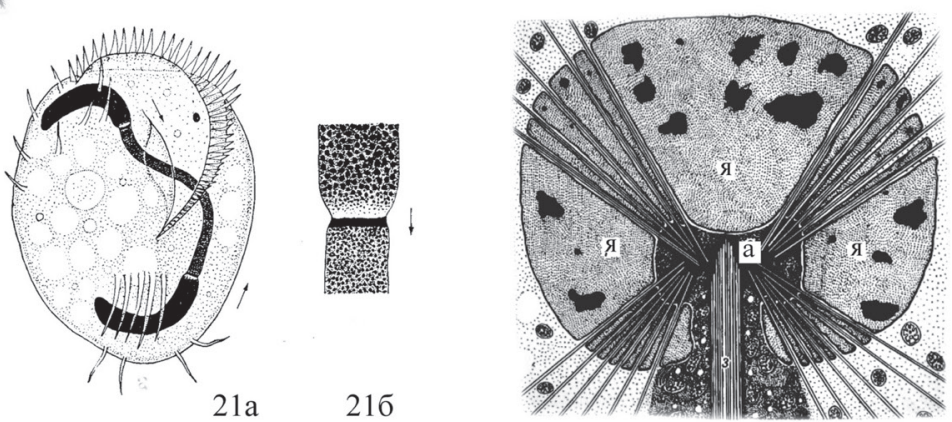

22

Рис 4. Полимеризация и дифференциация ядер в различных группах одноклеточных эукариот.

1-4: одноядерные формы: 1 - Euglypha sp. (Rhizopoda, Lobosea) (nо [19]); 2 - Chromulina pascheri (Chrysomonadinae) (nо [69]); 3 - Amoeba polypodia (Sarcodina, Amoebida) (nо [19]); 4 - Lampoxanthium pandora (Polycystina) (no [72]);

5-9: двуядерные и многоядерные формы: 5 - Arcella sp. (Rhizopoda, Lobosea) (по [19]); 6 - Lamblia intestinalis (Diplomonadina) (по [19]), 2 ядра и двойной набор органоидов; 7 - Pelomyха binucleata (Pelobiontidae) (по [70]); 8 - P. grubery (Pelobiontidae) (по Фролов, 2011); 9 - Astracantha actinastra (Cercozoa, Pheodaria) (по [72]), 2 ядра в центральной капсуле;

10-15: ядра фораминифер: 10 - Iridia sp. (Astrorhizata) (единственное ядро) (по [56]); 11 - Myхоtheca sp. (Astrorhizata) (несколько одинаковых ядер) (по [69]); 12 - Patellina corrugata (Spirillinata) (несколько одинаковых ядер) (по [69]), 13 а, 6 - Quinqueloculina sp. (Miliolata) (по [34]): a - удлиненный макронуклеус и мелкие генеративные ядра в трубчатой камере, 6 - поперечный срез той же камеры; 14 - Cibicides lobatulus (Rotaliata) (по [34]), один макронуклеус и множество мелких генеративных ядер; 15 - Rotaliella sp. (Rotaliata) (по [69]), один макронуклеус и 3 генеративных ядра;

16-2 1: ядра инфузорий: 16 - Tracheloraphis discolor (Ciliata, Gymnostomata, Karyorelictida) (по [67]), 12 ядерных групп по 4 макронуклеуса и 2 микронуклеуса в каждой; 17 - T. drachi (по [67]), ядерная группа: Ма - макронуклеус, н - нуклеола, x - хромоцентр макронуклеуса, Ми - микронуклеус; 18 - T. striatus (по [67]): сложное ядро с двумя микронуклеусами внутри; 19-20: один макронуклеус и один микронуклеус в инфузориях из кишечника морских ежей (Ciliophora, Oligohymenophorea) (по [19]): 19 - Entorhipidium tenue; 20 - Entodiscus indomitus;

21 - Euplotes patella (Ophryoscolecidae, Hypotrichacea) (по [44]): a - особь с макронуклеусом, реорганизованном полосками, 6 - диски полосок; 22 - Cystidosphaera sp.: сложное ядро (Polyсуstina) (по [64]), схема ультраструктуры ядра и погруженного в него аксопласта: я - ядро, a - аксопласт 
ка (Noctilluca), обычная в Черном море. У Trichomonas vaginalis (рис. 2, 11) 4 свободных жгутика, и 5-й расположен внутри ундулирующей мембраны (см. ниже), у Spironema multiciliatum (рис. 2, 12) кинетиды расположены в два ряда на переднем конце тела, у Hemimastix amphikineta (рис. 2, 13) - многочисленные кинеты расположены в бороздках по всему телу, у Malomonas cylindricus (рис. 2, 31) - множественные жгутики расположены на обоих концах тела. У Leptospironympha, Teratonympha и Kofoidia из кишечника термитов количество жгутиков возрастает многократно, у двух первых из них (рис. 2, 15, 16) множество жгутиковых рядов, которые могут в верхней части идти продольно, затем опоясывают все тело, у Kofoidia жгутики собраны в пучки, называемые лорикулами. Кроме лорикул, у жгутиконосцев могут образовываться ундулирующие мембраны перепонки, соединяющие жгутик с пелликулярной оболочкой клетки. Их волнообразные движения позволяют жгутику приобрести бо́льшую подвижность и маневренность (рис. 2, 3, 11).

У Opalina ranarum из задней кишки лягушки и Protoopalina axonucleata из кишечника головастика (класс Opalinata) жгутики покрывают все тело сплошными рядами (рис. 2, 18-20). Среди своеобразной немногочисленной группы Pelobiontida Mastigamoebidae на одноядерной стадии имеют один локомоторный жгутик (рис. 2, 21, 22), а у одноядерного Tricholimax единственный жгутик очень короткий и неподвижный (рис. 2, 23).

На рис. 3, $1 a$, 2, 3 можно видеть реснички нескольких видов инфузорий, покрывающих все их тело продольными или косо расположенными рядами - кинетами

\section{Полимеризация ядер в разных группах одноклеточных Eukaryota}

Большинство протистов одноядерны, но практически во всех их группах есть формы с двумя и более ядрами, в некоторых случаях число ядер может возрастать многократно. Примеры полимеризации ядер в разных систематических группах протистов приведены на рис. 4, 1-22.

Одноядерные формы среди Rhizopoda, Lobosea (Euglypha sp.), хризомонадин (Chromulina pascheri), саркодин (Amoeba polypodia), полицистин (Lampoxanthium pandora) даны на рис. 4, 1-4. Среди тех же Rhizopoda, Lobosea существуют и формы с бо́льшим числом ядер - Arcella sp. (рис. 4, 5) и другие виды. Точно так же среди жгутиконосцев есть и одноядерные (рис. 1, 1, рис. 2, 1-17), и многоядерные формы (рис. 1, 2-4). Число умножившихся ядер у них в составе полимеризованных кариомастигонтов (см. выше) может достигать нескольких десятков [12]. У Pheodaria 2 ядра расположены не прямо в цитоплазме, но находятся в дополнительной, объемлющей их центральной капсуле (рис. 4,9 ). Таким образом, у них произошла полимеризация внутриклеточных структур - образовалась новая надъядерная структура (центральная капсула). Как отмечалось выше, Pelobiontida могут быть одноядерными (в этом случае их единственный жгутик соединен с единственным ядром, расположенным в верхней части клетки (рис. 2, 22-23)), но бывают они и многоядерными (рис. $4,7,8$ ) и в этом случае утрачивают жгутик, по существу превращаясь в амебоидный двуядерный или многоядерный плазмодий.
Среди Opalinata одноядерных видов немного, большинство из них дву- и многоядерны, все ядра одинаковы (рис. 2, 18-20).

Плазмодизация у многих протистов часто бывает лишь временной и в этих случаях не может служить таксономическим признаком.

Несмотря на широкое распространение полинуклеарности в разных группах одноклеточных эукариот, этот признак закрепился и стал постоянным таксономическим признаком ранга типа лишь у двух таксонов протистов высокого уровня организации: у инфузорий и фораминифер.

Полимеризация ядер и другие особенности ядерного аппарата фораминифер будут подробно рассмотрены в специальной главе (см. ниже).

Полимеризация ядер инфузорий, представляющих одну из наиболее сложно устроенных и эволюционно продвинутых групп протистов, заслуживает особого внимания и также более детально будет рассмотрена ниже, поскольку у высших инфузорий эти процессы тесно связаны с процессами дальнейшей олигомеризации. У низших инфузорий (Trachelocercidae, Loxodidae и других) полимеризация их ядер видна наиболее отчетливо, число их соматических ядер (см. ниже) может достигать от двух до нескольких сотен (рис. 4,16$)$. Многоядерный род Stephanopogon с изоморфными ядрами, который ранее относили к низшим Ciliata, после новейших молекулярных и ультраструктурных исследований переведен в Heterolobosea [97]. К инфузориям теперь относят только формы с гетероморфными ядрами (см. ниже). Ядра некоторых инфузорий сильно увеличиваются в размерах и приобретают колбасовидную, четковидную, разветвленную форму ([44, рис. 62$]$ и рис. 3,5 и 4, 21a данной работы), что, согласно В.А. Догелю [12], представляет также одну из форм полимеризации.

Чрезвычайно интересный и необычный путь усложнения ядерного аппарата можно наблюдать у Cystidosphaera sp. (Polycystina), у которой аксопласт погружен в ядро (рис. 4, 22), или у Sphaerellaria. С точки зрения полимеризации здесь представлен особый случай, когда в одной структуре полимеризуются две разноуровневых структуры. Если рассматривать такой аппарат в целом, то он представляет случай олигомеризации (см. ниже). Такие случаи нередки, когда определение сущности процессов полимеризации/ олигомеризации зависит от того, рассматриваем ли мы структуру в целом или ее составляющие. Собственно говоря, рассмотренные выше кариомастигонты изнутри представляют структуру, состоящую из разноуровневых компонентов (тетрады жгутиков, базального зерна, парабазального тела, ядра и аксостиля), снаружи каждый из них можно рассматривать как олигомеризованную структуру. С этой точки зрения полимеризация уже сформированных кариомастигонтов (или акариомастигонтов) представляет сложный многоуровневый (многоэтажный) процесс полимеризации.

Обсуждая терминологический аспект полимеризации/олигомеризации, А.Д. Наумов с соавторами [35] считают, что «биохимическая 'полимеризация'» по существу аналогична процессу олигомеризации в смысле В.А. Догеля». По-видимому, и в случае биохимической полимеризации все зависит от того, рас-

Аксопласт (от греч. ахоn - ось, plastos - образованный), axoplastus особое тельце внутри ядра, в котором сходятся осевые нити скелета. 
сматриваем ли мы структуру сложной органической молекулы изнутри или снаружи: умножение одинаковых групп элементов внутри молекулы является, несомненно, процессом полимеризации, тогда как вся молекула целиком при взгляде снаружи представляет олигомеризованную структуру.

В прогрессивном развитии ядер одноклеточных эукариот большую роль играют процессы полимеризации геномов внутри ядер - полиплоидизация. Различают два типа внутриядерной полимеризации: с низкими и с очень высокими степенями плоидности («гиперполиплоидия») [43-45]. В последнем случае ядра называют полиэнергидными. Известны высокополиплоидные ядра среди Phaeodaria и Spumellaria, они широко распространены среди инфузорий, позже цитофотометрические исследования позволили обнаружить их у фораминифер $[4,6,98]$. Так, у агамонта Cibicides lobatulus количество ДНК в макронуклеусе возрастало в 30 раз [6, 7]. Низкополиплоидные ядра распространены в разных группах протистов более широко.

В.А. Догелем [12] отмечена также большая роль полимеризации клеточных органелл в процессах происхождения многоклеточных. Роль полимеризации ядер и внутриядерных геномов при этом особенно велика. Среди гипотез происхождения многоклеточности в последнее время предпочтение отдается колониальной теории по сравнению с происхождением через многоядерные плазмодии. По-видимому, имели место оба эти способа, и многоклеточность, так же как и половой процесс, возникала независимо и параллельно в разных группах протистов разными способами. Многие представители протистов как бы вырвались за пределы одноклеточности, и четкую границу между ними и многоклеточными провести невозможно. Л.Н. Серавин и А.В. Гудков [47] понимают под протистами «одноклеточных, а также многоклеточных, не достигших тканевого уровня, эукариот». Эти же авторы убедительно показали, что половой процесс, в основе которого лежат происходящие в ядре генетические изменения, возникал многократно параллельно и независимо в разных группах протистов, и в механизме его возникновения во многих случаях возможны существенные различия. Вероятно, с точки зрения полимеризации/олигомеризации размножение особей способом простого или множественного деления на уровне популяции или вида можно рассматривать как процесс полимеризации. А половое размножение, в какой-то степени, можно рассматривать как процесс олигомеризации, так как при этом происходит слияние двух клеток (гамет), а возникает лишь одна (зигота). На уровне высших многоклеточных при классическом варианте полового размножения две родительских особи часто дают жизнь лишь одному новому организму. Уменьшение числа женских половых клеток в процессе эволюции до одной (при сохранении огромного числа мужских половых клеток), вероятно, тоже можно рассматривать как процесс олигомеризации, при котором обеспечивается более высокая выживаемость потомства.

Полимеризация ядер, столь часто встречающаяся у протистов, среди Metazoa известна лишь в виде редких исключений (например, в слюнных железах некоторых насекомых). Она представляет своеобразный путь развития одноклеточных эукариот, которые как бы перепробовали в течение своего длительного развития множество различных способов интенсификации функций ядерного аппарата и всего одноклеточного организма.

\section{Полимеризация скелетных элементов в разных группах одноклеточных Eukaryota}

Многие одноклеточные эукариоты имеют органический или минеральный скелет. Элементы этого скелета также могут быть подвержены процессу полимеризации. О полимеризации аксостилей (осевых палочек) жгутиконосцев при умножении числа кариомастигонтов (см. выше) писал еще В.А. Догель [12]. У морских планктонных диатомей, которые создают до четверти всего органического вещества планеты, панцирь состоит из кремнезема. Может происходить полимеризация вставных колец (или дисков) таких панцирей, например, у Lauderia или Stephanodiscus (рис. 5, 1a, б). На том же рисунке (рис. 5, 2-7) даны примеры увеличения элементов скелета в разных группах Polycystina. У них может быть различное число скелетных камер (рис. 5, 2), сегментов (рис. 5, 3-5) или решетчатых сфер, которые могут быть единичными или располагаться одна в другой (рис. 5, 6-8). Одни из наиболее ярких примеров полимеризации числа скелетных элементов можно найти у фораминифер (рис. 5, 9-16). Число и форма камер фораминифер (а также их расположение) являются важными таксономическими признаками фораминифер в таксонах различного ранга, но их число неуклонно возрастало в каждой филогенетической линии в процессе эволюционного развития (рис. 7): от примитивных однокамерных раковин (рис. 5, 9) до 2-камерных (рис. 5, 12), затем состоящих из небольшого числа камер (5-30) (рис. 5, 10-14) и, наконец, до супермногокамерных форм с тысячами камер (рис. $5,15,16$ ).

\section{ОЛИГОМЕРИЗАЦИЯ МОРФОЛОГИЧЕСКИХ СТРУКТУР РАЗНЫХ ГРУПП ОДНОКЛЕТОЧНЫХ EUKARYOTA}

\section{Понятие олигомеризации по В.А. Догелю}

В работах $[11,12,14]$ В.А. Догель сформулировал понятие олигомеризации и определил ее эволюционное значение, уделив особое внимание проявлению процессов олигомеризации и у протистов, которая «до сих пор на одноклеточном уровне не рассматривалась» [12]. Под олигомеризацией он понимал тенденцию к уменьшению в числе гомологичных органов. Гомологичные органеллы и органы он часто называл «равнозначными», «однозначными», «однородными» частями. При этом он подчеркивал, что речь идет об уменьшении числа органов не только гомологичных, но и гомодинамных [14]. И процесс этот может идти разными способами: 1) часть гомологичных органов «просто редуцируется»; 2) олигомеризация может идти «посредством слияния» (А.Д. Наумов с соавторами [35] назвали этот способ литацией); 3) может происходить «выпадение части гомологичных или гомодинамных органов вследствие изменения ими прежней функции». Этот последний пункт «дает акцент относительному значению понятий го- 

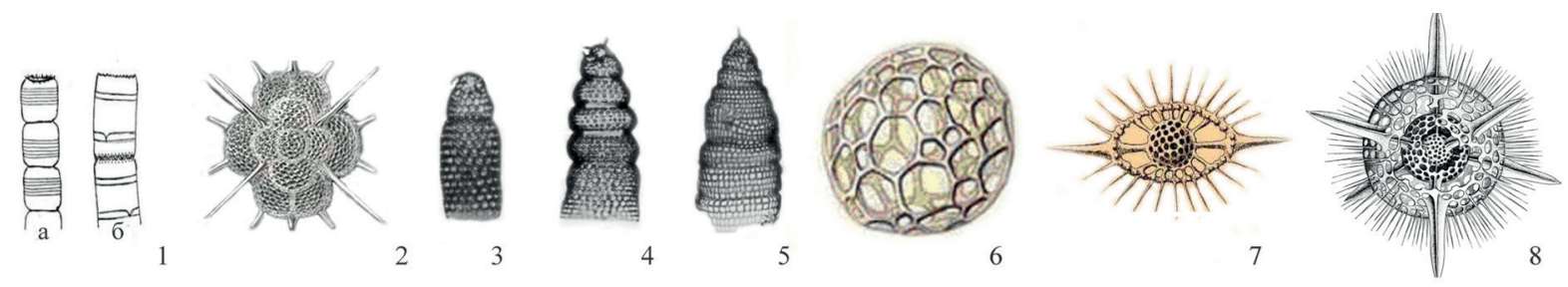

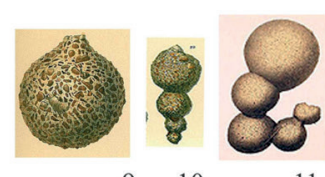

910

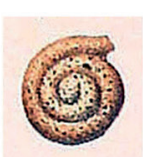

12

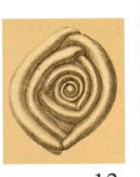

13

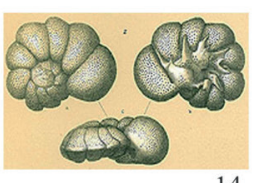

14
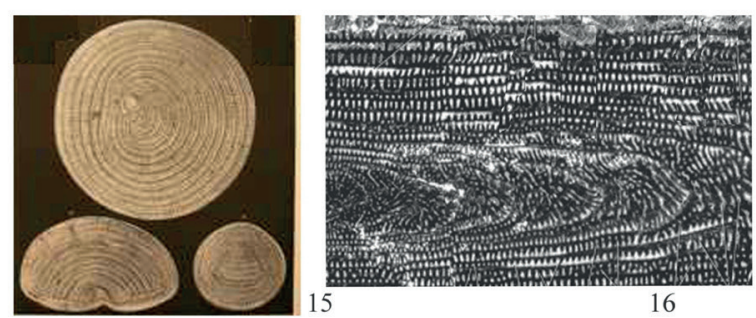

Рис. 5. Полимеризация элементов скелета в разных группах одноклеточных эукариот:

1 a, б - полимеризация вставных колец и дисков у Diatomea: a - Lauderia sp. (no [65]), 6 - Stephanodiscus sp. ([66]);

2-8: полимеризация частей скелета Polycystina. 2 - Cubotholus sp. (Polycystina) (по [72]); 3 - Siphocampium sp.; 4 - S. cf. seriatus; 5 - S. cf. cornutella (3-5 - Polycystina, по [62], увеличение числа сегментов раковины); 6 - Collosphaera polygona (Polycystina) (Haeckel, 1887), скелет в виде решетчатого шара; 7 - Heliodiscus phocodiscus (Polycystina) (по [92]), наружная раковина сплющенная, внутренняя шаровидная; 8 - Etmosphaera siphonosphaera (Polyсуstina, Stylosphaerida) (по [92]), скелет состоит из трех решетчатых шаров, заключенных один в другой;

9-16: увеличение числа камер у Foraminifera: 9 - Saccammina sphaerica (Hormosinana, Saccamminida), однокамерная раковина; 10 - Hormosina pilurifera (Hormosinana, Hormosinidae), несколько округлых камер в один ряд; 11 - Н. поrmani, несколько округлых камер в изогнутой раковине; 12 - Ammodiscus tenuis (Spirillinata, Ammodiscidae), псевдодвухкамерная раковина, за начальной овальной камерой (пролокулюсом) следует длинная вторая трубчатая камера в несколько оборотов; 13 - Cornuloculina tumidula (Miliolata, Miliolida), трубчатые камеры расположены по две в каждом обороте; 14 Lamellodiscorbis sp. (Rotaliata, Discorbida), вид с трех сторон, 2-3 оборота, образованных несколькими камерами каждый; 15 - Orbitolites sp. (Miliolata, Soritida), плоская раковина в виде тонкого диска с большим количеством камер и камерок (супермногокамерная); 16 - Praealveolina tenuis (Miliolata, Alveolinina), крупная удлиненно-яйцевидная раковина в разрезе со множеством камер и камерок первого и второго порядка; (1-5 по [63] 16 по [73])

мологичный и гомодинамный». Этим В.А. Догель подчеркивал важность физиологии и функции, их решающее значение.

Важнейшей заслугой В.А. Догеля является то, что он не только отметил, изучил и определил понятие олигомеризации, но и показал, что она связана «...с некоторыми сопряженными явлениями», имеющими эволюционное значение и помогающими определить уровень и вектор развития изучаемой группы организмов. К ним относятся приобретение олигомеризованными структурами организма фиксированного положения, бо́льших размеров и бо́льшей эффективности функций. Он также вскрыл и показал механизм действия связанных с олигомеризацией таких прогрессивных эволюционных изменений, как усиление централизации организма и его целостности (в противовес полимеризации, ведущей к усилению децентрализации), концентрации и интеграции организменных систем. Вместе с тем, олигомеризация ведет к дальнейшей дифференциации и специализации этих структур и организма в целом. Они настолько тесно связаны с процессом олигомеризации, что В.А. Догель назвал их второй ступенью, дальнейшей стадией олигомеризации. Еще в 1947 г. [12] В.А. Догель показал, что олигомеризация «обычно сочетается с далеко зашедшим вперед процессом прогрессивной эволюции» и потому наиболее ярко проявляется y Metazoa, а у протистов встречается гораздо реже и преимущественно в наиболее сложно устроенных и эволюционно продвинутых их группах.

\section{Олигомеризация и дифференциация двигательных органелл и ядер в разных группах одноклеточных Eukaryota}

Уменьшение числа двигательных элементов в результате их исчезновения у Peritricha и Oligotricha или в результате слияния ресничек в цирры и мембранеллы у Ophryoscolecida отмечал еще В.А. Догель [12]. Ряд таких примеров приведен на рис. 3, 1-13. У многих инфузорий вместо равномерного ресничного покрова, как это имеет место у Paramecium, могут быть один или несколько поясов одинаковых ресничек (рис. 3, 4-6). Например, два венчика ресничек у хищной инфузории Didinium sp., нижний венчик ресничек и околоротовой венчик у наружных паразитов рыб Trichodina pediculus, околоротовая и спинная ресничная зона у Ophryoscolex caudatum (рис. 3, 9), околоротовые и круговые зоны ресничек у других офриосколецид - Spirodinium и Polydinium (у последнего - несколько круговых зон) (рис. $3,7,8)$ и у крупной инфузории из желудка гориллы Troglodytella gorillae (Enthodiniomorpha) (рис. 3, 10).

Строение и расположение ресничек на теле инфузорий использовалось в классической морфологической систематике как важный таксономический признак, что отражалось в названиях их отрядов: Holotricha - равноресничные, Heterotricha - разноресничные, Peritricha - кругоресничные, Hypotrichaбрюхоресничные, Oligotricha - малоресничные. У Heterotricha тело покрыто двоякими (откуда и название) ресничками: 1) более мелкими, расположен- 
ными рядами по всему телу, и 2) мерцательными пластинками, произошедшими каждая из объединения одного или нескольких рядов более крупных ресничек (олигомеризация путем слияния). Последние окаймляют перистом, образуя спираль, идущую по направлению часовой стрелки. Эти мерцательные пластинки (мембранеллы) волнообразными движениями подгоняют пищевые частицы к ротовому отверстию и вглубь него (например, у трубача - рис. 3, 4). Таким образом, олигомеризованные в мембраны и мембранеллы реснички представляют одновременно дифференциацию ресничного аппарата, обычно тесно связанную с олигомеризацией. У равноресничных (Paramecium - рис. 3, 1б) реснички, которые расположены в перистоме (глотке), более длинные и более частые. Они отличаются от поверхностных ресничек и также представляют пример дифференциации. Сильно развитые реснички в глотке имеются и у $\mathrm{Bal}$ antidium coli (рис. 3, 26).

Другим случаем олигомеризации и одновременно дифференциации ресничек является образование цирр - слившихся пучков ресничек, расположенных обычно на нижнем конце тела (рис. 3,9$)$ или на брюшной стороне, как у Stylonichia или Euplotes (рис. 3, 11, 12). Каждая из цирр может быть образована слипанием нескольких десятков отдельных ресничек. С помощью этих цирр виды рода эуплотес бегают и даже прыгают по субстрату, напоминая прыжки блохи, а также активно используют эти цирры при плавании. Такие движения намного сложнее простого скольжения в воде, как у туфельки (Paramecium) или трубача (Stentor). У Stylonichia на спинной стороне имеются реснички, утратившие двигательную функцию и превратившиеся в чувствительные щетинки, что представляет собой хороший пример олигомеризации путем смены функций (см. выше). Сходный пример олигомеризации путем смены функций и дифференциации представляет Dactyltochiamis (Holotricha), у которого часть ресничек трансформировалась в стрекательные щупальца (рис. 3,13$)$ [15].

Среди жгутиконосцев приобретение одним из жгутиков Trichomonas vaginalis ундулирующей мембраны (рис. 2, 11) также представляет случай одновременной олигомеризации и дифференциации путем смены функций, при которой этот снабженный мембраной жгутик позволяет клетке совершать более разнообразные, быстрые и сложные движения. В приведенном А.В. Догелем примере с Calonymppha (см. выше) слияние осевых палочек (аксостилей) всех наборов органелл в один общий пучок также обеспечивает повышенную прочность этой структуры в результате олигомеризации путем слияния.

В процессе эволюции одноклеточных эукариот на основе возникшей во многих группах полимеризации ядер (см. выше), в двух самых высокоорганизованных их ветвях - инфузорий и фораминифер произошла морфофункциональная дифференциация ядер на соматические и генеративные. Это явление называют ядерным дуализмом или гетеморфизмом ядер протистов. Оно характерно только для одноклеточных эукариот и не встречается у многоклеточных. При ядерном гетеморфизме ядерный аппарат одной и той же клетки включает ядра двух типов. Соматические ядра, или макронуклеусы (Ma) обычно крупнее, они ответственны за нормальный клеточный метаболизм, вегетативные функции клетки, в них происходит синтез РНК. Количество ДНК в макронуклеусах превышает его количество в микронуклеусах в десятки, сотни, иногда даже в тысячи раз [36]. В микронуклеусах $(M i)$ идет генетическая рекомбинация. Митоз или мейоз претерпевают только микронуклеусы. В ходе полового процесса макронуклеусы обычно дегенерируют, а новые затем развиваются из микронуклеусов, то есть и те, и другие имеют общее происхождение.

Ядерный дуализм фораминифер возник лишь в некоторых наиболее прогрессивных их линиях и будет рассмотрен ниже в специальном разделе, посвященном этой группе. Ядерный дуализм инфузорий характерен для всех их представителей и служит одной из важнейших характеристик всего типа инфузорий (рис. 3, 1a, 9; рис. 4, 16-21). Число макронуклеусов и микронуклеусов у них может быть различным: чаще по одному макро- и микронуклеусу (рис. 3, 1a, 9; рис. 4, 19, 20, 21a), иногда тех и других может быть много (рис. 4, 16-18), - до нескольких десятков. Во времена В.А. Догеля [12] считалось, что в последнем случае произошла полимеризация обоих типов ядер. Однако более поздние исследования показали, что многоядерные инфузории, такие как Loxodes, Tracheloraphis discolor (рис. 4, 16-18) представляют низшую ступень в развитии инфузорий, и уменьшение числа соматических и генеративных ядер до одного $M a$ и одного $M i$ произошло в процессе прогрессивного развития в результате олигомеризации их числа [44]. Иногда эти многочисленные ядра низших инфузорий могут быть объединены в несколько групп, содержащих по несколько макро- и микронуклеусов, например, у Tracheloraphis discolor по 4 макронуклеуса и 2 микронуклеуса в каждой, то есть происходит олигомеризация на уровне групп (слияние в меньшее число групп), но сами группы внутри остаются сложными и полимеризованными. У T. striatus образуется всего одна такая полимеризованная группа (рис. 4, 18). На этих примерах видно, что процессы полимеризации и олигомеризации развиваются здесь взаимосвязанно. И.Б. Райков [44, 45] видит в подобных группах тенденцию к образованию полигеномных ядер путем слияния отдельных диплоидных макронуклеусов в сложное ядро.

В крупных полиплоидных макронуклеусах инфузорий могут быть участки, бедные ДНК и богатые ею. Последние И.Б. Райков назвал ортомерами [44]. Так происходит дифференциация внутри самого́ ядра, а сами такие ядра относятся к гетеромерным. У Euplotes patella и других Нурotrichida и некоторых Holotricha с крупными гетеромерными макронуклеусами произошла еще более глубокая дифференциация: в них появляются светлоокрашенные диски реорганизационные полоски [44] (рис. 4, 21a, б).

Благодаря столь сложному ядерному аппарату с полиплоидией макронуклеусов и ядерным гетероморфизмом, которому предшествовала многоядерность, клеткам инфузорий обеспечивается интенсификация вегетативных функций и процессов метаболизма.

\section{Полимеризация и дифференциация ядер и некоторых цитоплазматических структур у фораминифер}

Традиционно при изучении фораминифер использовались их хорошо сохраняющиеся скелеты, изучение их цитоплазматических структур отставало от 
степени изученности в других группах протистов. Наличие раковины у ныне живущих форм сильно затрудняло такие исследования. Тем не менее, ядерный дуализм был обнаружен у нескольких представителей в эволюционно продвинутых линиях.

У большинства представителей самого примитивного класса Astrorhizata ${ }^{4}$ имеется лишь одно ядро (рис. 4,10$)$, но у некоторых их родов имеет место полимеризация числа ядер, например у Penardogromia или Myxotheca sp. (рис. 4, 11).

В класce Spirillinata полимеризация ядер является, по-видимому, характерной чертой этого таксона и наблюдалась у современных Spirillina и Patelli$n a$ (рис. 4, 12) [69]. Все перечисленные здесь формы являются гомокариотными - их ядра одинаковы по форме и функции. В класcе Rotaliata у их низших представителей с агглютинированной раковиной тоже обнаружено по несколько одинаковых ядер, например, до 4 ядер у Trochammina (класс Textulariana) [85]. У высших представителей классов Rotaliata и Miliolata c секреционной известковой раковиной (coответственно в подклассах Rotaliana и Miliolana) ядра дифференцированы на соматические и генеративные (рис. $4,13 a, 6,14,15$ ). Соматическое ядро у них обычно одно и крупное, тогда как генеративных ядер много и они значительно более мелкие. Объем соматического ядра превосходит таковой генеративного ядра в два, в десятки, иногда и в тысячи раз. Количество РНК в макронуклеусе в три раза выше, чем в микронуклеусе, значительно выше и количество протеинов, а количество ДНК в обоих типах ядер примерно одинаково. Разделение функций отражается и на морфологии дифференцированных ядер. Хорошо известными примерами ядерного дуализма у фораминифер являются Cibicides lobatulus, Rotaliella heterocariotica, Metarotaliella parva (Rotaliana), Globigerina bulloides (Globigerinana), Peneroplis pertusus, Sorites marginalis, Quinqueloculina sp., (Miliolana). У некоторых представителей роталиат и милиолят произошла полимеризация соматических ядер - их не одно, а несколько, например, у Rosalina columbiensis, Glabratella sulcata, Globigerinoides rubber (Rotaliata), Sorites marginalis (Miliolata).

Характер ядерного аппарата фораминифер претерпевает сильные изменения в течение разных стадий их жизненного цикла. Так, на стадии агамонта (бесполое поколение) низшие фораминиферы остаются одноядерными на протяжении почти всей стадии, и лишь перед самым процессом размножения их ядро делится, образуя ядра следующего поколения - гамонтов (половое поколение). У высших представителей большинства остальных классов (данные по классу Nodosariata отсутствуют) агамонт с самого начала многоядерный. Вероятно, стадия деления ядер агамонтов низших представителей перед процессом размножения постепенно закрепилась в процессе эволюции как более длительная стадия. Интересно, что у одного из агамонтов примитивных представителей класса Astrorhizata - у однокамерной Allogromia есть не одно, а два поколения агамонтов, и второе из них, в отличие от первого, - многоядерное. Это наблюдение подтверждает предположение А.В. Догеля о том, что полимеризация часто возникает как не доведен-

\footnotetext{
4 Здесь и далее используется классификация, основанная на морфологических данных [32, 34, 82], которая в основных чертах совпадает с результатами молекулярно-генетических исследований $[84,87]$
}

\section{ный до конца процесс размножения [12].}

Как и во многих других группах протистов, особенно инфузорий, у фораминифер тоже имеет место полиплоидизация - полимеризация числа геномов в ядре. Впервые она была открыта у Patellina corrugata и Rotaliella heterocariotica [98], позже у Cibicides lobatulus [4-7].

Обычный путь эволюции ядерного аппарата - полимеризация ядер, полимеризация геномов (полиплоидия) и затем олигомеризация ядер.

В отличие от инфузорий, у фораминифер не произошло олигомеризации генеративных ядер, на этом пути изменения ядерного аппарата они оказались продвинутыми менее, чем инфузории. Судьба соматического ядра у фораминифер также иная, чем у инфузорий, - оно разрушается в процессе мейоза и не передается по наследству, в то время как у инфузорий происходит обмен ядрами во время своеобразного, только у них существующего полового процесса конъюгации.

И полиплоидизация, и полимеризация числа ядер возникают в результате не доведенного до конца процесса деления. Оба эти процесса полимеризации происходят на разных структурных уровнях организма: первое внутри ядра, второе внутри клетки. Оба они ведут к активизации и мобилизации функций и самого ядра, и всего организма. Не случайно именно представители наиболее продвинутых подклассов фораминифер (Rotaliana и Miliolana), имеющих полимеризованные полиплоидные ядра, создают супермногокамерные формы, достигающие иногда нескольких сантиметров в размере, с наиболее сложной системой внутренних коммуникаций, жизненная стратегия некоторых из них сравнима с таковой многоклеточных животных, продолжаясь более года, в редких случаях даже несколько лет. Необходимость централизации и интеграции у таких крупных протистов, имеющих сложную многокамерную раковину с относительно автономными камерами, требует бо́льшей функциональной эффективности и, соответственно, более сложного и мощного ядерного аппарата.

И вся цитоплазма клетки фораминифер до некоторой степени может быть вовлечена в процесс полимеризации и дифференциации. Так, у низших агглютинированных однокамерных фораминифер она не дифференцирована на эндо- и эктоплазму, и она слабо дифференцирована, без четкой границы между этими двумя слоями у некоторых более продвинутых групп. Но у самых высоко специализированных и эволюционно продвинутых групп подклассов Rotaliana и Spirillinana эктоплазма отделена от остальной цитоплазмы клетки морфологически и функционально: она циркулирует в системе каналов, проходящих между камерами. На рис. 6, 3 показан участок системы таких каналов Assilina sp., (Nummulitida, класc Rotaliata). Hottinger [73], детально изучавший эти тончайшие системы у представителей роталиат, показал, что в них циркулирует эктоплазма, богатая кислородом. Таким образом, на одноклеточном уровне организации возникла система поразительной степени сложности, функционально сходная с кровеносной системой многоклеточных! Системы каналов возникли параллельно и достигли большой степени сложности у высших представителей лишь двух многокамерных классов (рис. 6) - Rotaliata и 

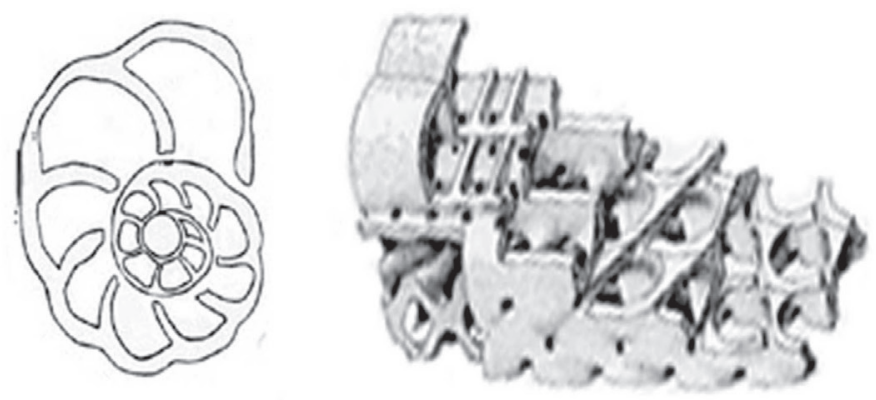

1

2

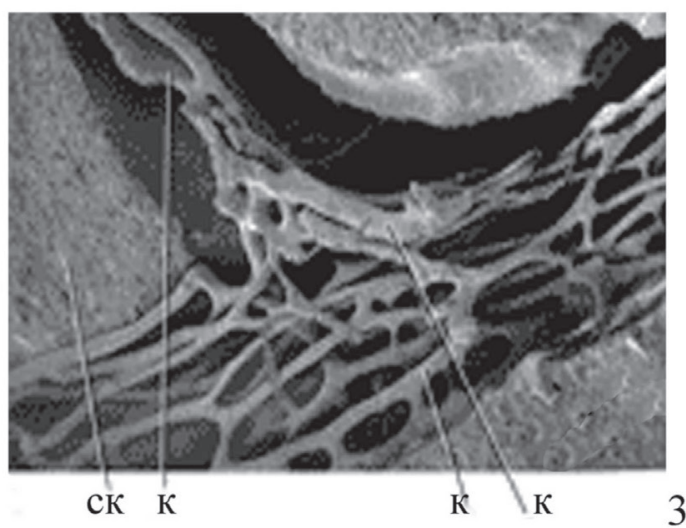

Рис. 6. Форамены, столоны и каналы - сложные системы многокамерных фораминифер (2, 3 по [73]):

1 - форамены многокамерных фораминифер, от которых они и получили свое название, на примере Cibicides sp. (Rotaliata); 2 - схема столонов (дополнительных проходов между камерами, дополняющих систему внутренних устьев - фораменов);

3 - каналы Assilina sp. (Nummulitida, класc Rotaliata), проходящие между камерами: к - каналы, ск - стенка камер

Spirillinata, в класcе Nodosariata известен лишь один случай своеобразной слабо развитой системы каналов у рода Delosina. Изучение высших спириллинат с помощью электронного микроскопа позволяет обнаружить их у все бо́льшего числа форм $[89,90]$.

В другом подклассе роталиат - Globigerinana, которые ведут планктонный, а не донный, как большинство фораминифер, образ жизни, - наружная эктоплазма за пределами раковины образует широкий слой или наполненную пузырьками воздуха капсулу (у Hastigerina), напоминающую калимму радиолярий и обеспечивающую флотирование.

Разделение цитоплазмы на два слоя можно рассматривать как полимеризацию с дальнейшей дифференциацией функций, что сказывается в увеличении специфической активности клетки.

\section{Полимеризация камер у фораминифер}

Наиболее наглядно процессы полимеризации в развитии фораминифер можно проследить в изменении строения их скелета, представленного раковиной, сначала органической или агглютинированной (налипшие на цитоплазму песчинки или другие частицы скрепляются цементом различного происхождения), затем постепенно в процессе эволюции становящейся полностью известковой секреционной. Все ранее принятые классификации, включая последнюю наиболее употребительную классификциаю Лёблика и Таппан [77], строились, в первую очередь, на основе строения стенки раковин и объединяли все агглютинированные формы, включающие все возможные типы строения раковин, в один таксон, а остальные известковые типы раковин сходной с ними морфологии - в 11 отдельных таксонов соответственно их морфологии. Новый подход был впервые предложен в 1980 г. [29] и в дальнейшем разработан более детально $[32,34,79,82]$. В новой системе было выделено 5 основных филогенетических линий развития (классов - рис. 7), основанных в первую очередь на морфологии раковин и их устья. Агглютинированные и секреционные формы сходного строения объединялись в одном классе, в качестве разных подклассов. Таким образом, преимущественное значение в классификации группы придавалось морфологии раковин, а строение стенки рассматривалось как важный, но соподчиненный признак. По- нять развитие и усложнение форм внутри всего типа фораминифер и внутри каждой из его филогенетических линий помог тщательный сравнительно-морфологический анализ, основанный на выявленных А.В. Догелем [11-15] закономерностях эволюционного развития: полимеризации, олигомеризации и последующей дифференциации и интеграции. Результаты молекулярно-генетических исследований $[84,87]$ подтвердили правильность основных линий развития (классов) фораминифер, выделенных на основании этого морфологического подхода.

Образование многокамерных раковин происходило в процессе эволюции, начиная с кембрия, параллельно во всех классах, хотя в классе Astrorhizata с преимущественно однокамерными формами он лишь слабо намечался.

Среди трех основных способов полимеризации, сформулированных С.А. Подлипаевым с соавторами [38], фораминиферы использовали два из них - фиссацию (подразделение на части уже существующей камеры) и дополнительно образование новой камеры в результате достроечного роста, что соответствует двум путям, обозначенным В.А. Догелем [12]: путем разделения первоначально имевшихся зачатков и путем новообразований (см. выше).

На рис. 8 даны примеры обоих этих способов полимеризации числа камер у фораминифер, из которых второй можно рассматривать как более прогрессивный: у одноосных - Earlandia, Calligella, Parathikinella, Hormosinella (класс Nodosariata) (рис. 8, 2-5) и Sarmatiella (класc Miliolata) (рис. 8,6) происходит лишь частичное разделение полости камеры в результате пережимов наружной стенки, у более продвинутых одноосных нодозариат новые камеры образуются путем достроечного роста, при этом каждая последующая камера может слегка охватывать предыдущую (рис. 8, 7-9). У свернутых раковин, как при навивании в одной плоскости (спирально-плоскостном), так и при навивании в виде пирамидки (трохоидном) также возможны эти два типа полимеризации камер. Так, у свернутого в одной плоскости Ammodiscus paковину предложено называть псевдо-двухкамерной [30], потому что ее начальная округлая камера (пролокулюс) отделена от последующей лишь пережимом стенки (рис. 8, 10). У спирально-плоскостных псевдомногокамерных Costanella, Carbonella и Eoph- 


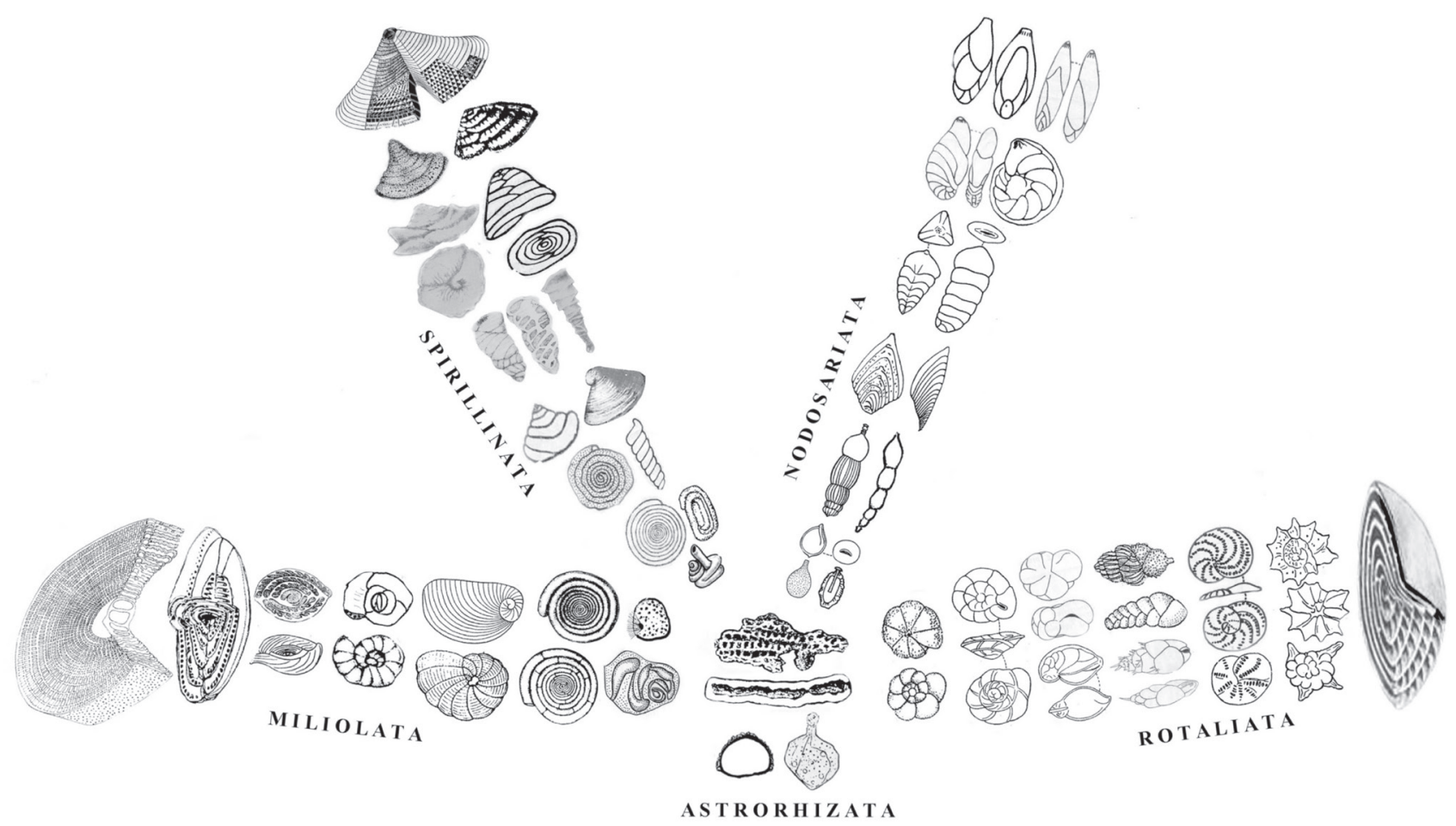

Pис. 7. Типы строения однокамерных и многокамерных раковин в разных классах фораминифер. B класce Astrorhizata только однокамерные формы, все остальные классы включают многокамерные формы, в класcах Miliolata и Rotaliata paзвитие привело к возникновению супермногокамерных раковин

thalmidium (класс Miliolata) полость трубчатой камеры поделена на псевдокамеры отложениями раковинного вещества на дне камеры (рис. 8, 11-13), а у Costanella (рис. 8,11 ) еще и пережимами стенки. Редкий случай полимеризации камер внутри агглютинированной трубчатой камеры представляет собою род Starobogatovella (рис. 8,14 ) - ее внутрикамерные перегородки образованы лишь органическим веществом, и поэтому специалисты расходятся во мнении, к какому из классов ее следует отнести: к Astrorhizata или Miliolata. У остальных представленных на рисунке родов (рис. 8, 15-19), относящихся к классам Miliolata и Rotaliata, полноценные камеры образуются в результате дополнительной полимеризации - каждая новая камера нарастает заново. Среди них у супермногокамерных Nummulites (Rotaliata) (рис. 8, 18) и Alveolina (Miliolata) (рис. 8, 19) число камер возрастает многократно и может достигать нескольких сотен или даже тысяч.

У некоторых многокамерных раковин полость их камер может быть частично подразделена неполными внутренними септами на камерки. Такие дополнительные подразделения встречаются во всех многокамерных классах фораминифер, например, у Multiseptida (Nodosariata), Riveroina (Miliolata), Pseudopatellina (Spirillinata), Heterostegina (Rotaliata) (рис. $8,21 a, \sigma-24)$. Во всех этих случаях имеет место многоэтажная полимеризация - раковина состоит из камер, образовавшихся в результате дополнительной полимеризации, последние - из камерок, возникших в результате фиссации. Иногда такие камерки встречаются и у однокамерных раковин более примитивного класса Astrorhizata (Daitrona - рис. 8, 20).

Интересно отметить, что, в отличие от многоклеточных животных с полимеризованным числом клеток, у фораминифер полимеризованные камеры не полностью отделены от предыдущих и сохраняют с ними связь через системы внутренних устьев - фораменов, давших название и всей группе фораминифер (несущие форамены) (рис. 6, 1). Полимеризованные камеры, связанные узкими проходами, через которые сообщается цитоплазма соседних камер, в какой-то степени напоминают клетки растений, где отдельные клетки не полностью изолированы и связаны между собой цитоплазматическими мостиками (плазмадесмами), образуя синцитий. Так своеобразно проявляются пути эволюции на разных уровнях организации живого. У многоклеточных животных цитоплазматические мостики между клетками изредка возникают лишь как временное явление, например, цитоплазматические мостики между эндокринными клетками крыс [47].

Некоторые однокамерные и сравнительно просто устроенные фораминиферы тоже могут достигать крупных размеров, например, известны палочковидные раковины Bathysiphon длиной 12 и даже 18 см. К сожалению, строение их ядерного аппарата и других органелл клетки не исследовались, и не ясно, за счет чего достигается такая интенсификация роста и других функций. В.А. Догель [12] рассматривал общее увеличение размеров тела протистов или их органелл как третий, сравнительно редкий путь полимеризации (см. выше).

\section{Полимеризация и олигомеризация устьев и устьевых структур у фораминифер}

Среди других структур клетки фораминифер огромную функциональную роль имеет устье - отверстие раковины, как правило, на конце последней камеры, через которое выходят наружу ретикулоподии и осуществляется связь с внешней средой (передви- 

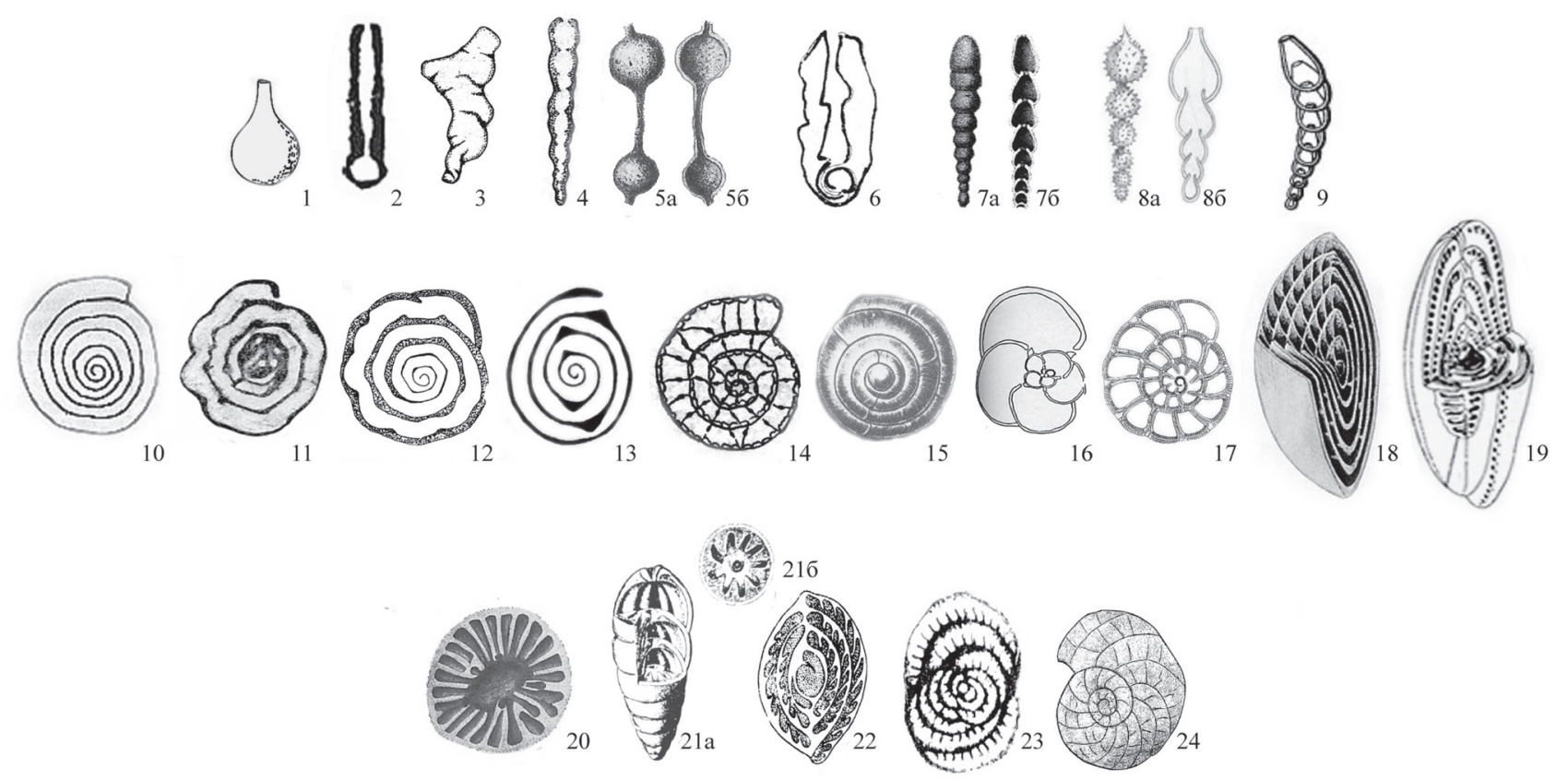

Рис. 8. Полимеризация камер у фораминифер:

1-9: образование псевдокамер и камер у одноосных раковин (1-5 и 7-9 - класc Nodosariata; 6 - класc Miliolata): 1 - Lagena sp., однокамерная раковина; 2 - Earlandia sp.; 3 - Calligella sp.; 4 - Parathikinella sp.; 5 a, 6 - Hormosinella sp.; 6 - Sarmatiella sp.; 7 a, 6 - Pseudonodosinella sp., агглютинированная стенка раковины; 8 a, 6 - Nodosaria sp.: a - целая раковина, 6 - в разрезе; 9 - Enantiodentalina sp. (8, 9 - полностью секреционная известковая стенка раковины; 2-4, 6 - неполное подразделение полости раковины происходит за счет сужения стенки раковины, подразделения на камеры не образуется, либо образуются псевдокамеры; 2, 3, 4, 7-9 - полное разделение на камеры при достроечном росте);

10-19: образование псевдокамер (10-14) и камер (15-19) у спирально-свернутых раковин ( 14 - класс Astrorhizata; 10-13, 15, 16, 19 - класс Miliolata, 17, 18 - класc Rotaliata): 10 - Ammodiscus sp., псевдодвухкамерная раковина: за пролокулюсом следует вторая неподразделенная трубчатая камера; 11 - Costanella sp.; 12 - Carbonella sp.; 13 - Eophthalmidium sp.; 14 - Starobogatovella sp., трубчатая камера с агглютинированной стенкой внутри разделена органическими (тектиновыми) поперечными перегородками; 15 - Fisherinella sp.; 16 - Buzasina sp.; 17 - Rotalia sp.; 18 - Nummulites sp.; 19 - Alveolina sp. (секция по [77]);

20-24: внутренние подразделения камер у однокамерных и многокамерных форм: 20 - Daitrona sp., полость однокамерной раковины с радиальными подразделениями, класс Astrorhizata (по [77]); 21 a, 6 - Multiseptida sp., класc Nodosariata, многокамерная раковина с внутренними радиальными перегородками: а - вид сбоку, секция, б - вид сверху (по [77]); 22 Riveroina sp., класс Miliolata, многокамерная форма с трубчатыми камерами по две в обороте, поделенными внутри неполными косыми перегородками; 23 - Pseudopatellina sp., класс Spirillinata; 24 - Heterostegina sp., класc Rotaliata, многокамерная раковина с внутренними перегородками

жение, захват пищи и т. д.). Эти структуры в процессе эволюции также подвергались процессам полимеризации, причем их умножение и усложнение тоже происходили параллельно в разных филогенетических линиях (классах). Так, у многих близкородственных родов происходит увеличение числа устьевых отверстий на устьевой поверхности раковины от единичного до множественного (рис. 9): в классе Miliolata y Pyrgo, у Dendritina - единичное устье (рис. 9, 1, 3), а у Cribropyrgo, Peneroplis (рис. 9, 2, 4) - множественное, в класce Nodosariata у Lagenoglandulina (рис. 9, 5) единичное устье, у Amphimorphina (рис. 9, 6) - множественное, в классе Spirillinata у Patellina (рис. 9, 7) - единичное устье, у Haurania (рис. 9, 8) - множественное. Сходная картина у близких родов класса роталиата: у Gyroidina, Haplophragmoides, Goesella (рис. 9, 9, 11, 13) - устье единичное, у Cribroparrella, Barkerina, Cribrogoesella (рис. 9, 10, 12, 14) - множественное.

Полимеризации подвергаются и внутренние структуры устья, что хорошо видно на примере нескольких родов милиолят (рис. 9, $15 a-3$ ): число зубов - внутренних структурных элементов устья, служащих опорой интенсивному в этом месте току цитоплазмы - увеличивается от одного до двух или нескольких (рис. 9, $15 a-2)$. Затем эти зубы могут разнообразными способами сливаться, при этом число устьевых отверстий увеличивается от 3 до нескольких (рис. 9, 15 - -3$)$. Олигомеризация и полимеризация проявляются здесь как взаимосвязанные процессы. Сходную картину можно наблюдать и в строении внутренних устьевых структур нодозариат. У последних слияние внутренних устьевых элементов может происходить не только в области устья, но и по всей раковине от камеры к камере. Так, например, сливаются ентосолениевые (= внутренние) устьевые трубки Ellipsoidina (рис. 10,196 ) в единую интегрирующую устьевую систему. У рода Bombulina (рис. 10, 19a) эти трубки не достигают устья предыдущей камеры. Единые интегрирующие устьевые системы, образовавшиеся путем слияния сложных зубных пластинок каждой камеры, широко распространены в классе роталиат. 

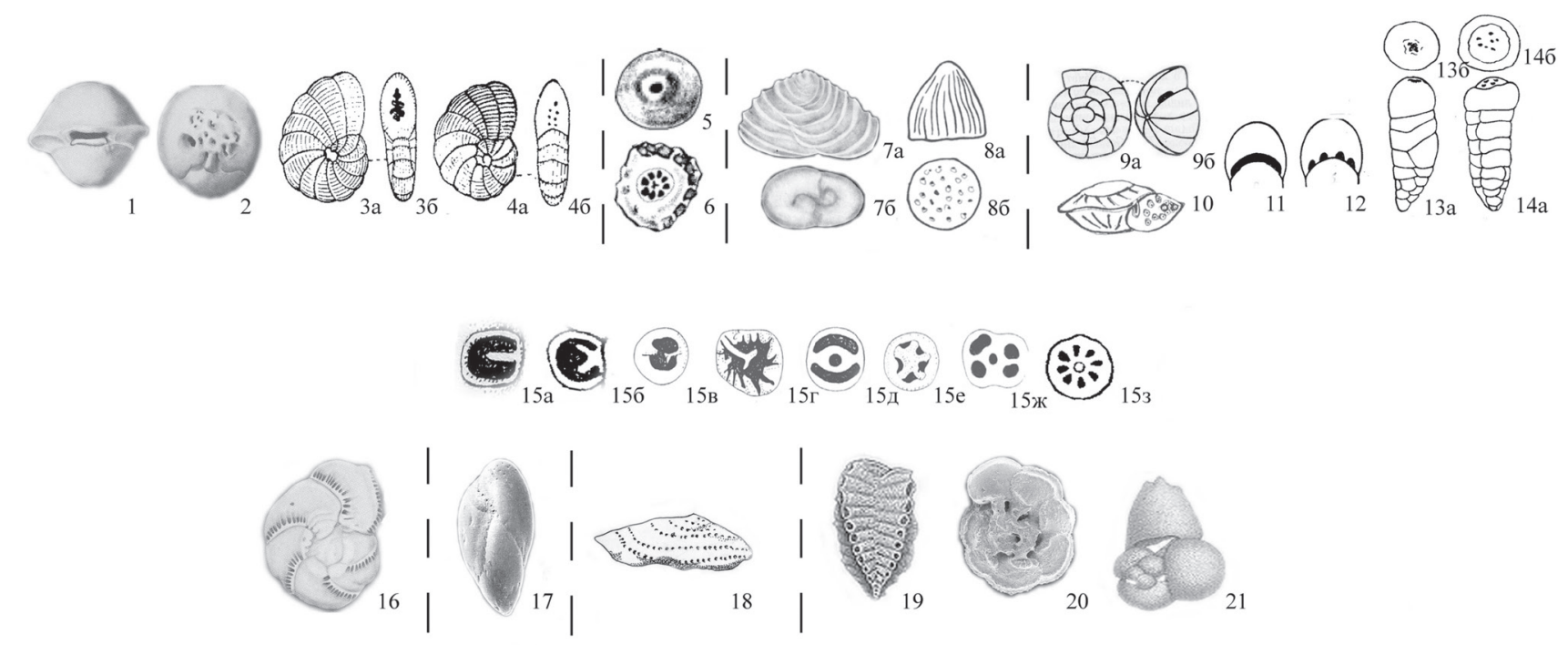

Pис. 9. Полимеризация устьев у фораминифер (пунктирная линия разграничивает классы):

1-14: полимеризация главного устья в разных классах фораминифер;

1-4: класс Miliolata: 1 - Pyrgo sp., единичное устье; 2 - Cribropyrgo sp., множественное устье; 3 a, 6 - Dendritina sp., единичное устье: a - вид с боковой стороны, 6 - вид со стороны устья; 4 a, 6 - Peneroplis sp., множественное устье: $a$ - вид с боковой стороны, б - вид со стороны устья;

5, 6: класс Nodosariata: 5 - Lagenoglandulina sp., единичное устье, вид со стороны устья; 6 - Amphimorphina sp., множественное устье, вид со стороны устья;

7, 8: класс Spirillinata: 7 - Patellina sp., единичное устье: а - общий вид раковины, 6 - вид со стороны устья; 8 - Haurania sp.: а - общий вид раковины, б - вид со стороны устья;

9-14 - класс Rotaliata; 9 a, 6 - Gyroidina sp., единичное устье: а - вид со спиральной стороны, б - вид со стороны устья; 10 Cribroparrella sp., множественное устье, вид со стороны устья; 11 - Haplophragmoides sp., единичное устье; 12 - Barkerina sp., множественное устье; 13 a, 6 - Goesella sp., единичное устье: a - общий вид раковины, б - вид со стороны устья; 14 a, 6 - Cribrogoesella sp., множественное устье: a - общий вид раковины, б - вид со стороны устья;

15 a-з - полимеризация внутренних структур устья (зубов) у разных представителей отряда Милиолида (класc Miliolata); 16-21: дополнительные устья в разных классах фораминифер: 16 - Polysegmentina sp., дополнительные шовные устья (класс Miliolata); 17 - Delosina sp., дополнительные шовные устья (класc Nodosariata); 18 - Trocholinopsis sp., дополнительные шовные устья (класс Spirillinata); 19 - Plotnikovina sp., дополнительные периферические устья на концах камер; 20 - Globotruncana sp., дополнительные пупочные устья на пупочной стороне раковины; 21 - Globigerinoides sp., дополнительные шовные устья

Интегрирующие устьевые системы отграничивают часть цитоплазмы от остальной части камер и, таким образом, приводят к дифференциации цитоплазмы. Так процесс олигомеризации приводит к усложнению строения фораминифер и к возникновению новой структуры организменного уровня, что можно рассматривать как полимеризацию организменных структур. Такой же, но еще более сложной структурой организменного уровня, тоже тесно связанной с устьем и с дифференциацией цитоплазмы, можно считать и системы каналов высших роталиат и спириллинат (рис. 6, 3).

Множественные устья однокамерных раковин, не имеющих четкой локализации и разбросанных беспорядочно по всей ее поверхности, напротив, следует считать первично множественными [78]. Следующей ступенью в развитии таких форм можно считать появление единичного устья, которое обычно бывает бо́льших размеров и строго фиксировано в своем расположении, как, например, у Saccammina. Такое устье можно рассматривать как олигомеризованное и вторично единичное. В.А. Догель [12] также отмечал, что уменьшение числа органелл или органов «сопровождается обычно строгим фиксированием их положения в теле и увеличением размеров и эффективности остающихся в наличии органов».
Примером полимеризации устьев можно считать не только полимеризацию отверстий основного (главного) устья на устьевой поверхности раковин, но также появление в некоторых группах дополнительных устьев, расположенных чаще всего в швах между камерами или на периферических концах камер (рис. 9, 16-21). Они возникают параллельно в разных классах у наиболее продвинутых родов и особенно развиты в классах Spirillinata (рис. 9, 18) и Rotaliata (рис. 9, 19-21). У последних в подклассе Globigerinana (рис. 9, 21) они, так же как их основное устье, сильно увеличены в размерах как приспособление к планктонному образу жизни. Появление в процессе эволюции дополнительных устьев можно рассматривать как появление устьевой структуры нового уровня.

В отличие от полимеризации камер при достроечном росте, когда процесс идет постепенно и последовательно, полимеризация устьев происходит одновременно.

Все описанные выше полимеризованные и олигомеризованные структуры устья фораминифер представляют эволюционные изменения, способствующие лучшему взаимодействию с внешней средой и интенсификации функциональной активности, чем способствуют повышению конкурентоспособности обладающих ими родов. 

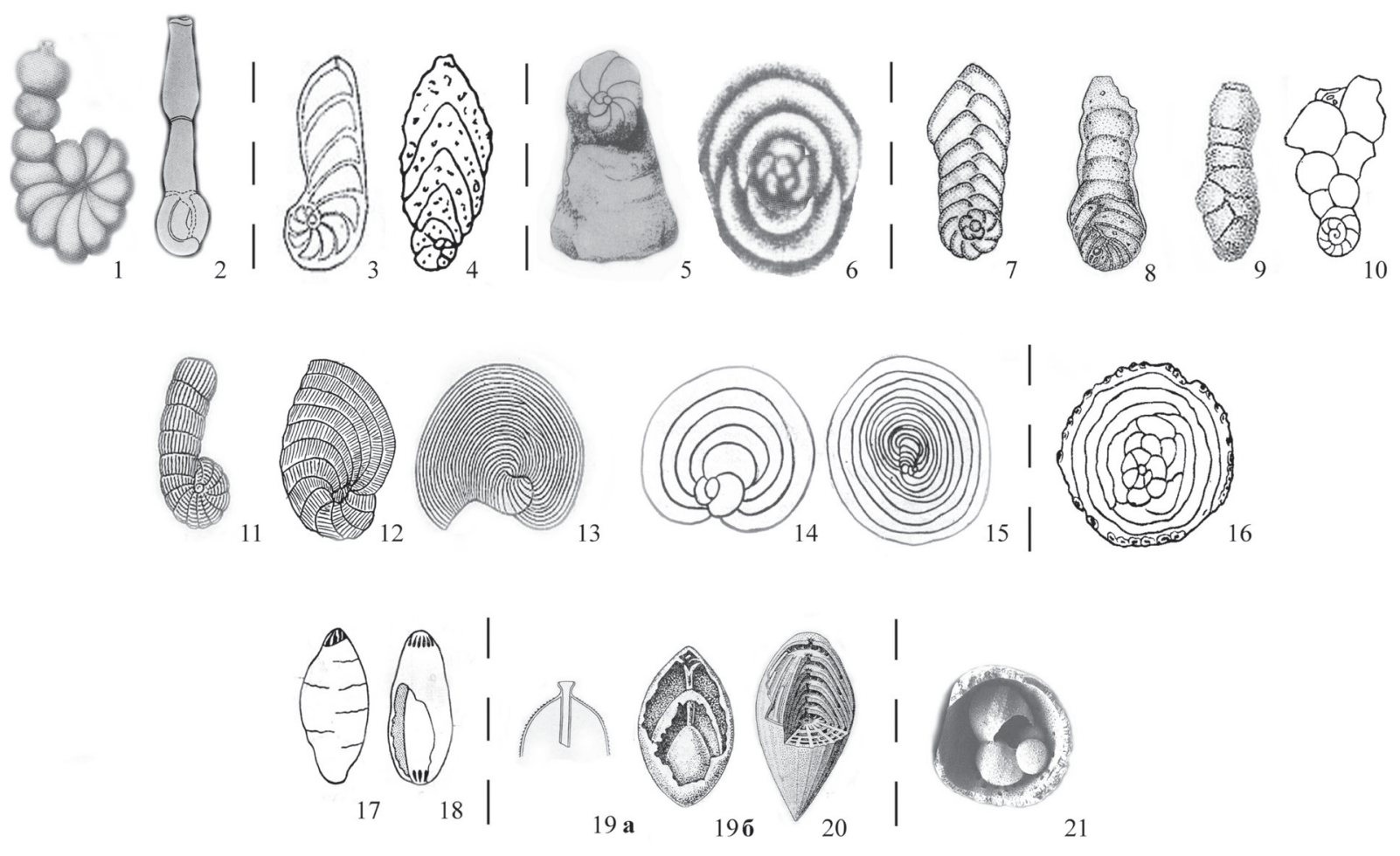

Рис. 10. Олигомеризация камер в разных классах фораминифер (пунктирная линия разграничивает классы):

1-16: уменьшение числа камер в более поздних отделах раковин: 1 - Monalysidium sp., (класc Miliolata), плоскоспиральносвернутый начальный отдел, содержащий до 10 камер в обороте, сменяется более крупными однорядными камерами; 2 Articularia sp., (класс Miliolata), начальный отдел из трубчатых камер, навитых по квинквелокулиновому типу по 2 в каждом обороте, сменяется крупными длинными камерами, расположенными в один ряд; 3 - Astacolus sp. (класc Nodosariata), начальный спирально-плоскостной отдел из 7-8 камер сменяется косо расположенными однорядными камерами; 4 - Flabellammina sp. (класc Nodosariata), спирально-плоскостной начальный отдел и V-образные поздние камеры, расположенные в один ряд; 5 - Urgonina sp. (класс Spirillinata), низко-трохоидная многокамерная начальная часть и последующие расширяющиеся однорядные камеры; 6 - Patellinella sp. (класс Spirillinata), раковина трохоидная, мелкая начальная часть сменяется более крупными камерами по две в каждом обороте; 7 - Spiroplectammina sp., многокамерная плоскоспиральная часть сменяется выпрямленным двурядным отделом; 8 - Vulvulina sp., начальный отдел двурядный, поздний однорядный; 9 - Siphogenerina sp., начальный отдел двурядный, поздний однорядный; 10 - Vagocibicides sp., начальный отдел трохоидный, поздний двурядный; 11-16: тенденция к образованию конечных циклических камер: 11 - Spirolina sp.; 12, 13 - Peneroplis sp.; 14, 15 - Vandenbroeckia sp.; 16 - Annulocibicides sp. (7-10, 16 - класс Rotaliata);

17-21: последняя камера объемлет предыдущие. 17, 18 Nevillina sp., (класc Miliolata); 19 a, 6 - представители класса Nodosariata: a - Bombulina с короткой ентосолениевой трубкой, не доходящей до следующей камеры, 6 - Ellipsoidina sp., ентосолениевые трубки всех последовательных камер соединены в единую систему; 20 - Colaniella sp. (класc Nodosariata); 21 - Orbulina sp. (класс Rotaliata)

\section{Олигомеризация камер у фораминифер}

Большое число полимеризованных камер у представителей 4 классов фораминифер создает базу и возможность их дальнейшей олигомеризации. И такие процессы идут во всех этих филогенетических линиях, отличаясь качественным своеобразием в каждой из них.

Наиболее частым проявлением олигомеризации является уменьшение числа камер в конечных оборотах свернутых раковин или в их конечных выпрямленных отделах (рис. 10, 1-16). Так, сокращение числа камер в конечном выпрямленном отделе до одной или двух можно проиллюстрировать на примере Monalysidium, Articularia и Peneroplis (класс Miliolata) (рис. 10, 1, 2, 11), Astacolus и Flabellammina (класс Nodosariata) (рис. 10, 3, 4), Urgonina (класс Spirillinata) (рис. 10, 5), Spiroplectammina, Vulvulina, Siphogenerina и Vagocibicides (класс Rotaliata) (рис. 10, 7-10).
Причем начальные отделы этих раковин могут иметь разнообразное строение: могут быть спирально-плоскостными (рис. 10, 1, 3, 4, 7, 8), клубковидно свернутыми (рис. 10, 2), трохоидными (рис. 10, 5, 9, 10). У трохоидной Patellinella (класс Spirillinata) (рис. 10, 6) трохоидная раковина не образует выпрямленного отдела, но число камер сокращается от пяти в начальном обороте до двух в последнем. В классе Miliolata у спирально-свернутых раковин камеры последних оборотов постепенно расширяются до веерообразных (рис. 10, 12, 13) и циклических (рис. 10, 14, 15). Встречается такой способ олигомеризации камер и в класce Rotaliata: у Annulocibicides начальные обороты трохоидной раковины с пятью-шестью камерами в каждом обороте окружаются с оборотами со все меньшим числом камер в каждом из них, и, наконец, в последнем обороте камеры становятся циклическими - каждая составляет целый оборот (рис. 10, 16). 
Другой, более редкий способ олигомеризации камер фораминифер заключается в том, что последняя камера охватывает все предыдущие обороты (рис. 10, 17-21). Так же как и в рассмотренном выше первом случае олигомеризации камер, заключенные внутри последней камеры начальные стадии разных родов могут иметь различное строение: характерное для милиолят у Nevillina (рис. 10, 17, 18), одноосное расположение камер, при котором каждая последующая сразу полностью охватывает предыдущую у Ellipsoidina и Colaniella (класc Nodosariata) (рис. 10, $19 a$, $6,20)$, трохоидное у Orbulina, при котором лишь последняя сферическая камера охватывает предыдущие (рис. 10, 21).

Во всех приведенных здесь примерах олигомеризованные камеры значительно крупнее в размерах, чем предыдущие, что позволяет усилить их функцию. Они как бы берут на себя роль нескольких, более мелких предыдущих камер, при этом общий, часто бо́льший объем функций выполняется ме́ньшим числом структур.

В.А. Догель [12] показал на нескольких группах протистов, что полимеризация ведет к дезинтеграции организма и уменьшению его целостности, тогда как олигомеризация, напротив, повышает его целостность, создавая возможность более эффективной регуляции с использованием ме́ньшего числа структур. С процессом олигомеризации и дифференциации тесно связаны и процессы интеграции. Так, у многокамерных и супермногокамерных фораминифер связь цитоплазмы внутренних камер с другими частями раковины и с внешней средой становится затрудненной. В результате нарушается равновесие между организмом как системой и окружающей его внешней средой, состояние системы разбалансируется [88]. В этом случае процесс интеграции, возникновение интегрирующих систем облегчают взаимодействие между дезинтегрированными частями организма и помогают восстановить утраченное системой равновесие. Эта третья стадия (интеграция) представлена в раковинах фораминифер системами столонов (рис. 6, 2), интегрирующих устьевых систем (рис. 10,196$)$ и каналов (рис. 6,3$)$, возникших в дополнение к более примитивной системе фораменов (рис. 6,1$)$. Система каналов фораминифер устроена поразительно сложно для одноклеточного уровня организации (см. выше).

\section{Дифференциация камер у фораминифер}

Как и в других группах протистов (см. выше), полимеризация и олигомеризация камер фораминифер часто связаны с их дифференциацией.

Первые, наиболее примитивные фораминиферы были однокамерными (рис. $11,1,2$ ) либо псевдодвухкамерными (рис. 11, 12). Лишь в самых простейших случаях, в начале процессов полимеризации камер дифференциации не происходит, и все камеры одинаковы по форме и размеру, как это имеет место у одноосных Grigelis и Saccamminopsis (рис. 11, 3, 4). У слабо эволюционно продвинутых форм разных классов камеры в той или иной степени дифференцированы по размеру (Lunucammina, Dolosella, Loeblichia - рис. $11,5,13,14)$. У более продвинутых родов дифференциация в размерах проявляется более отчетливо (рис. 11, 6-11, 15, 17). Еще более явственны различия в строении камер у родов с гетероморфной раковиной (рис. $10,1-21$; рис. 12,19 ) и в тех случаях, когда часть камер, обычно в более поздних оборотах, имеет дополнительные внутренние подразделения и отличается морфологически (рис. 11, 18, 20). Наибольшей морфологической дифференциации достигают супермногокамерные формы (рис. 11, 16, 21) высших роталиат и милиолят и некоторые представители спириллинат, например, Orbitolina (рис. 11, 23), у которой последовательные обороты камер имеют различные, очень сложные внутренние подразделения, что в какой-то степени можно сравнить с дифференциацией клеток в разных тканях многоклеточных. Очевидно, и функционально эти разные слои камер орбитолин ведут себя различно. Глубокая морфологическая и функциональная дифференциация привела к появлению у многих эволюционно продвинутых многокамерных и супермногокамерных форм к появлению крупных начальных эмбриональных камер, например, у Lepidocyclina в классе Rotaliata (рис. 11, 22). Эмбриональные камеры встречаются и у представителей двух других многокамерных классов - Miliolata и Spirillinata, но отсутствуют у Nodosariata. Функциональная дифференциация камер зашла довольно далеко и у некоторых других родов: у Tretomphalus снизу трохоидной раковины расположена специальная флотирующая камера (рис. 11, 24), а у планктонного рода Globigerinoides последняя камера удлиненной формы, отличающаяся от предыдущих шарообразных камер, служит выводковой камерой.

Наличие дополнительных устьев у многих родов в параллельных классах можно рассматривать как дифференциацию устьев на основные и дополнительные. Часто дополнительные устья появляются не на ранних, а на более поздних возрастных стадиях раковины, таким образом, происходит дополнительная дифференциация камер.

Описанная выше глубокая дифференциация камер не только по форме, но и по функции у некоторых продвинутых групп фораминифер свидетельствует о большой сложности их организации и высокой степени прогрессивного развития фораминифер.

Постепенные усложнения строения раковин фораминифер (увеличение числа камер с последующей их олигомеризацией, увеличение числа устьев, усложнение устьевых аппаратов и интегрирующих систем) проходили в течение долгого эволюционного развития фораминифер параллельно во всех их 4 многокамерных классах (рис. 12) при сохранении качественного своеобразия в каждом из них. Закономерность этих усложнений напоминает таблицу Менделеева и в некоторых случаях делает возможным предсказание появления форм с определенными чертами строения. Так, в подотряде Miliolina y форм с разными типами навивания камер (рис. 13) встречаются устья с внутренним или наружным пластинчатым зубом и множественные устья. Однако у раковин с сигмовидным типом навивания последний тип устья (множественный) не был обнаружен, хотя теоретически мог бы существовать. Впоследствии такой род Longiapertina был описан. Таким образом, система, построенная с учетом явлений полимеризации/олигомеризации и связанных с ними последующих усложнений, может обладать и прогностической ценностью. 

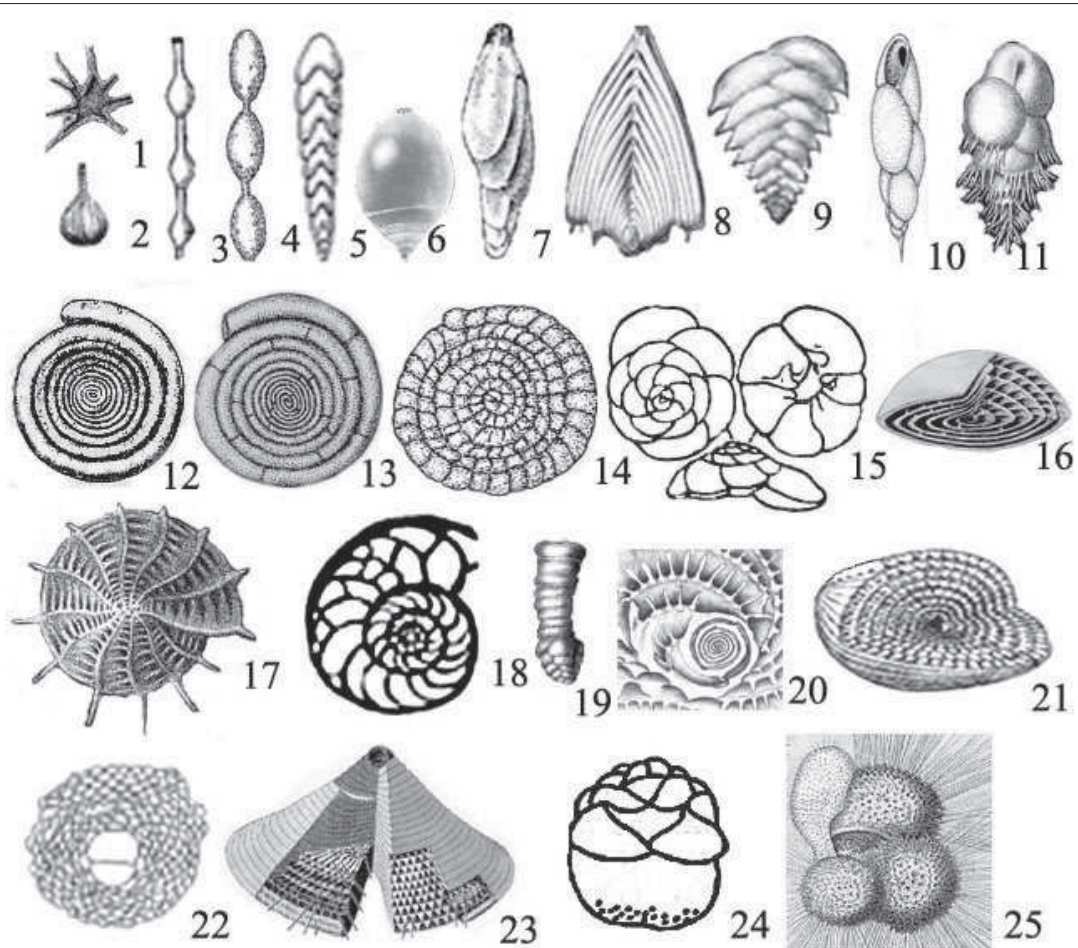

Рис. 11. Дифференциация камер в разных классах фораминифер: 1 - класс Astrorhizata; 2-8 - класc Nodosariata; 9-11, 15-19, 22, 25 - класс Rotaliata; 12-14, 20, 21 - класс Miliolata; 23, 24 - класс Spirillinata (по [82]):

1, 2: однокамерные раковины: 1 - Astrorhiza sp. (класс Astrorhizata); 2 - Lagena sp. (Nodosariata);

3, 4: полимеризованные недифференцированные камеры равного размера: 3 - Grigelis sp.; 4 - Saccamminopsis sp.;

5-25: камеры дифференцированы по размеру: 5 - Lunucammina sp.; 6 - Pseudonodosaria sp., камеры быстро возрастают в размерах; 7 - Gorisella sp., удлиненные каплевидные камеры; 8 - Frondicularia sp., V-образные камеры; 9 - Bolivinella sp.; 10 - Stainforthia sp.; 11 - Bulimina sp.; 12 - Cornuspira sp., с округлой начальной камерой (пролокулусом), за которым следует длинная неподразделенная трубчатая камера; 13 - Dolosella sp., следующая за пролокулусом трубчатая камера в конечных оборотах разделена на самостоятельные камеры трубчатой формы; 14 - Loeblichia sp., камеры равной формы, почти не возрастающие в размерах, сохраняют трубчатый облик; 15 - Discorbis sp., трохоидная раковина с округло-трапециевидными камерами, быстро возрастающими в размерах; 16 - Nummulites sp., супермногокамерная раковина; 17 - Elphidium sp.; 18 Heterostegina sp., камеры дифференцированы на начальные неподразделенные и последние с внутренними перегородками; 19 - Clavulina sp., камеры дифференцированы по форме и положению; 20 - Discospirina sp., камеры дифференцированы на начальные трубчатые неподразделенные камеры и последующие с внутренними перегородками; 21 - Neoschwagerina sp.; 22-25: раковины с глубоко дифференцированными камерами, разного строения и функции: 22 - Lepidocyclina sp., часть раковины, в центре крупные зародышевые камеры; 23 - Orbitolina sp., на вершине конуса крупная зародышевая камера, поздние камеры имеют различное внутреннее строение; 24 - Tretomphalus sp., трохоидная раковина с крупной пузыреобразной нижней камерой, служащей для расселения; 25 - Globigerinoides sp. с последней выводковой камерой

Рис. 12. Схема параллельного развития 4 многокамерных классов фораминифер. Сплошные линии показывают границы между классами, пунктирные - между подклассами (по [33] с изменениями). В каждом из 4 классов низшие подклассы имеют агглютинированную стенку раковин, высшие - секреционную известковую, с особым типом ультраструктуры в каждом из них. Классы Miliolata и Nodosariata начинали свое развитие с однокамерных раковин, класс Spirillinata - с псевдодвухкамерных. В конечных ветвях классов Miliolata и Rotaliata возникли супермногокамерные формы, классов Spirillinata и Rotaliata - формы с системой каналов. В последнем классе сформировались формы, приспособленные к жизни в верхних слоях воды (подкласс Globigerinana).

Класс Spirillinata. Подкласс Ammodiscana: 1 - Ammovertellina; 2 - Ammovertella; 3 - Ammodiscus; 4 - Turritelella; 5 - Repmanina; 6 - Arenoturrispirillina; 7 a, b - Tetrataxis. Подкласс Spirillinana: 1 - Miliospirella; 2 - Glomodiscus; 3 - Archaediscus dubitabilis; 4 - A. karreri; 5 - Cylindrotrocholina; 6 - Howchinia; 7 - Lasiotrochus (в центре раковины - система каналов); 8 Babelispirrillina; 9 - Coronipora; 10 - Trocholina; 11 -Spirillina; 12 - Spirotrocholina (a, b - внешний вид раковины, с - схема системы каналов, аксиальное сечение); 13 - Annulopatellina; 14 - Paleopatellina.

Класс Miliolata. Подкласс Miliamminana: 1 - Recurvoides; 2 a, b - Charentia; 3 - Lituola; 4 - Alzonella; 5 - Dentostomina; 6 Sigmoilopsis; 7 - Ammomassilina; 8 - Reticulinella. Подкласс Miliolana: 1 - Squamulina; 2 - Cornuspira; 3 - Cornuspiroides; 4 Gheorgianina; 5 - Cornuloculina; 6 - Spirophthalmidium; 7 - Discospirina; 8 - Fischerinella; 9 - Zoyaella; 10 - Spirolina; 11 a, b - Danubiella; 12 - Quinqueloculina; 13 - Neoalveolina; 14 a, b-Dendritina; 15 - Laevipeneroplis; 16 - Parasorites. 


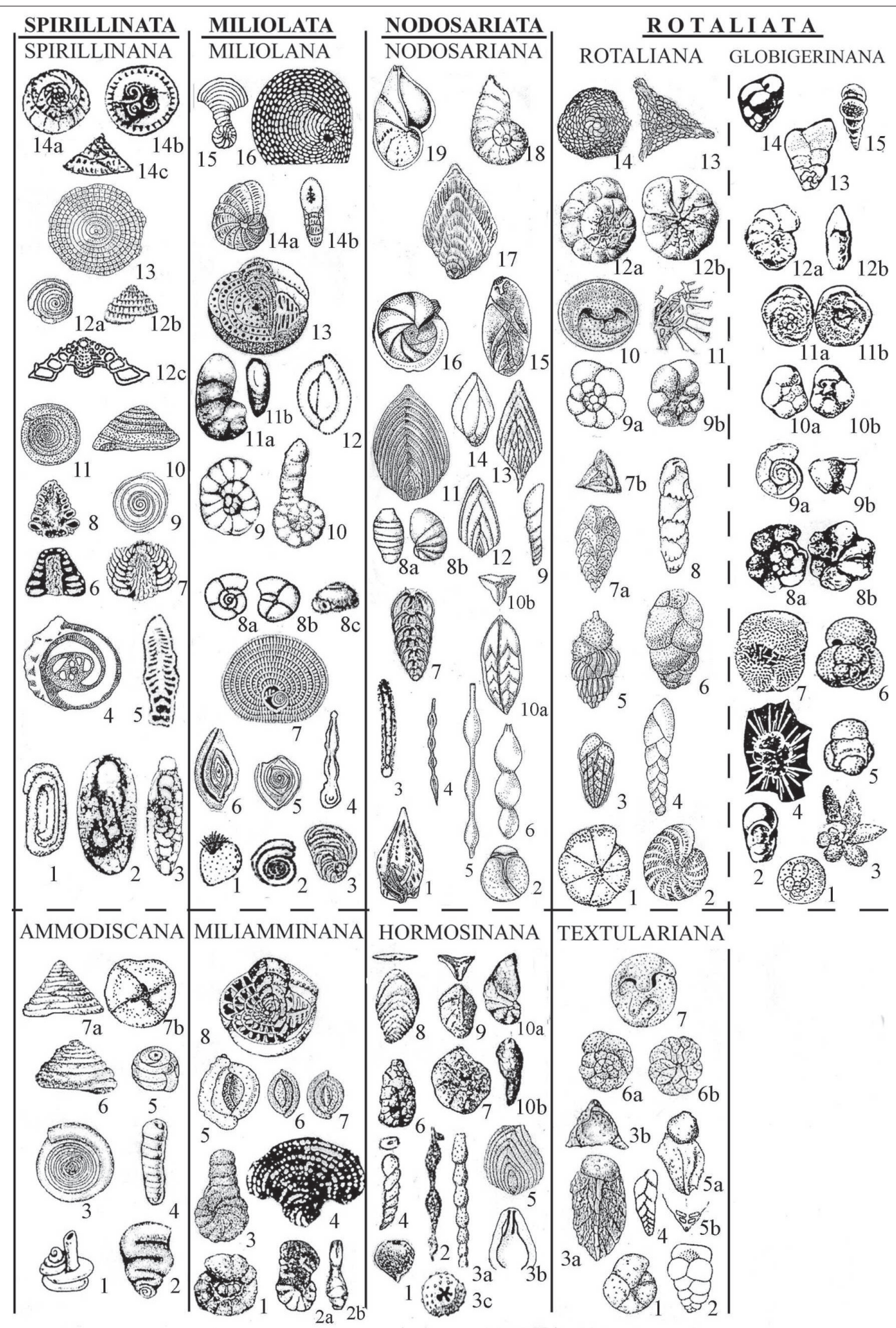

Класс Nodosariata. Подкласс Hormosinana: 1 - Saccammina; 2 - Hormosinella; 3 a, b, c - Nodosinum (а - вид раковины снаружи, b - на разрезе раковины видно устье с продольными ребрами, с - вид сверху со стороны устья); 4 - Adelungia; 5 Pseudopalmula; 6 - Nouria; 7 - Agardhella; 8 - Flabellammina; 9 - Triplasia; 10 a, b - Ammomarginulina ( $а$ - вид сбоку, b - вид со стороны устья). Подкласс Nodosariana: 1 - Lagena; 2 - Parafissurina; 3 - Syzrania; 4-5 - Grigelis; 6 - Nodosaria; 7 - Multiseptida; 8 a, b - Lingulina (a - микро, b - макросферическое поколение); 9 - Marginulina; 10 a, b - Tristix; 11 - Kурhоруха; 12 - Dyofrondicularia; 13 - Flabellina; 14 - Polymorphina; 15 - Laryngosigma; 16 - Lenticulina; 17 - Planularia; 18 - Hemicristellaria; 19 - Saracenaria.

Класс Rotaliata. Подкласс Textulariana: 1 - Haplophragmoides; 2 - Minouxia; 3 a, b - Gaudryina; 4 - Pseudobolivina; 5 a, b Clavulina ( $a$ - внешний вид раковины, b - срез начальных камер), 6 a, b - Asterotrochammina; 7 - Tiphotrocha (вид с пупочной стороны). Подкласс Rotaliana: 1 - Bermudezinella; 2 - Elphidium; 3 - Brizalina; 4 - Bolivinellina; 5 - Euuvigerina; 6 - Sporobulimina; 7 a, b-Reussella; 8 - Pseudobuliminella; 9 a, b - Discorbis; 10 - Neoconorbina (вид с пупочной стороны); 11 - Rotalia (фрагмент системы каналов); 12 a, b - Ammonia; 13 - Baculogypsinoides (горизонтальный срез мегалосферической особи с каналами); 14 - Eulinderina (срединное сечение мегалосферической формы). Подкласс Globigerinana: 1 - Orbulina; 2 Globanomalina; 3 - Boliella; 4 - Hastigerina; 5 - Globigerinita; 6 - Globigerinoides; 7 - Globigerina; 8 a, b - Rotalipora; 9 a, b Globorotalia; 10 a, b-Rugoglobigerina; 11 a, b-Globotruncana; 12 a, b-Plananomalina; 13 - Heterochelix; 14 - Gumbelitria; 15 - Laterostomella (вид сбоку) 


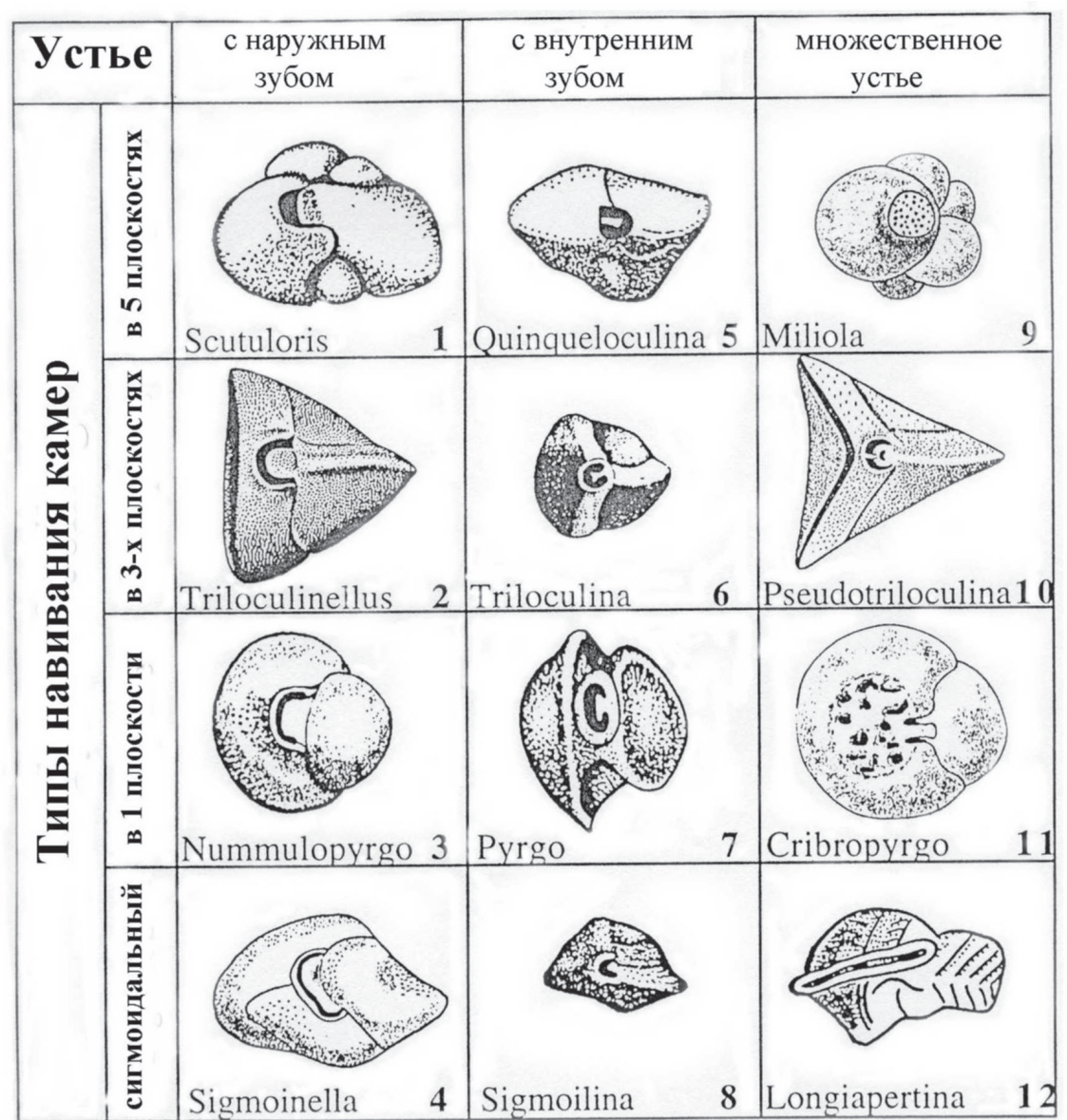

Pис. 13. Строение устья милиолят (Foraminifera) с разным типом навивания камер (по [33])

\section{ПОЛИМЕРИЗАЦИЯ И ОЛИГОМЕРИЗАЩИЯ У МНОГОКЛЕТОЧНЫХ}

Процессы полимеризации/олигомеризации у многоклеточных изучены наиболее подробно. После фундаментальной монографии В.А. Догеля [14] и множества работ по отдельным группам животных $[1,3,9,10,25,48$ и др.] и растительных организмов $[16,27,28,53,57$ и др.] нет необходимости рассматривать здесь этот процесс. Также В.А. Догелем и его последователями было показано, что в развитии многоклеточных ведущую роль играют процессы олигомеризации. Может быть, стоит все же подчеркнуть, что и у многоклеточных роль полимеризации на ранних этапах их развития была достаточно высока стоит только представить весь путь развития от примитивных кишечнополостных до млекопитающих, в течение которого происходило постоянное увеличение размеров тела, числа клеток, а затем числа и разнообразия возникающих тканей. С повышением уровня организации различных групп многоклеточных роль олигомеризации, дифференциации и интеграции неуклонно возрастала.

Возможно, стоит упомянуть о принципиально новой точке зрения, рассматривающей доброкачественные опухоли многоклеточных организмов как эволюционный путь увеличения числа клеток, клеточной массы, изменения генов и создание резерва для образования новых тканей и органов [75]. Такие опухоли переходят в злокачественные в случае нарушения регуляции и централизации функций цен- тральной нервной системой. Эти взгляды открывают возможность новых путей лечения онкологических заболеваний.

\section{НАЧАЛЬНЫЕ ПРОЦЕССЫ ПОЛИМЕРИЗАЦИИ У ВИРУСОВ И БАКТЕРИИ}

\section{Начальные процессы полимеризации у вирусов}

Среди трех гипотез происхождения вирусов (гипотезы «сбежавших генов», регрессивной гипотезы, рассматривающей вирусы как дегенерировавшие одноклеточные паразиты, и гипотезы доклеточного происхождения вирусов из первичных генетических элементов) наиболее вероятной представляется третья из них. Е. Кунин [24], выдающийся современный специалист в области современной эволюционной биологии, считает, что «вирусоподобный характер генетического резервуара на доклеточной стадии эволюции жизни является логической необходимостью». Он убедительно проследил множественные связи между геномами вирусов и клеточных форм жизни и определенно отвел вирусам «место во владениях биологии» и возможность стоять у самых истоков жизни, выстроив логический умозрительный сценарий вирусного мира для доклеточной эволюции.

В последнее время вирусы все чаще рассматривают в контексте общей модели эволюции. С этой точки зрения интересно посмотреть, применим ли и к ним закон полимеризации/олигомеризации. 

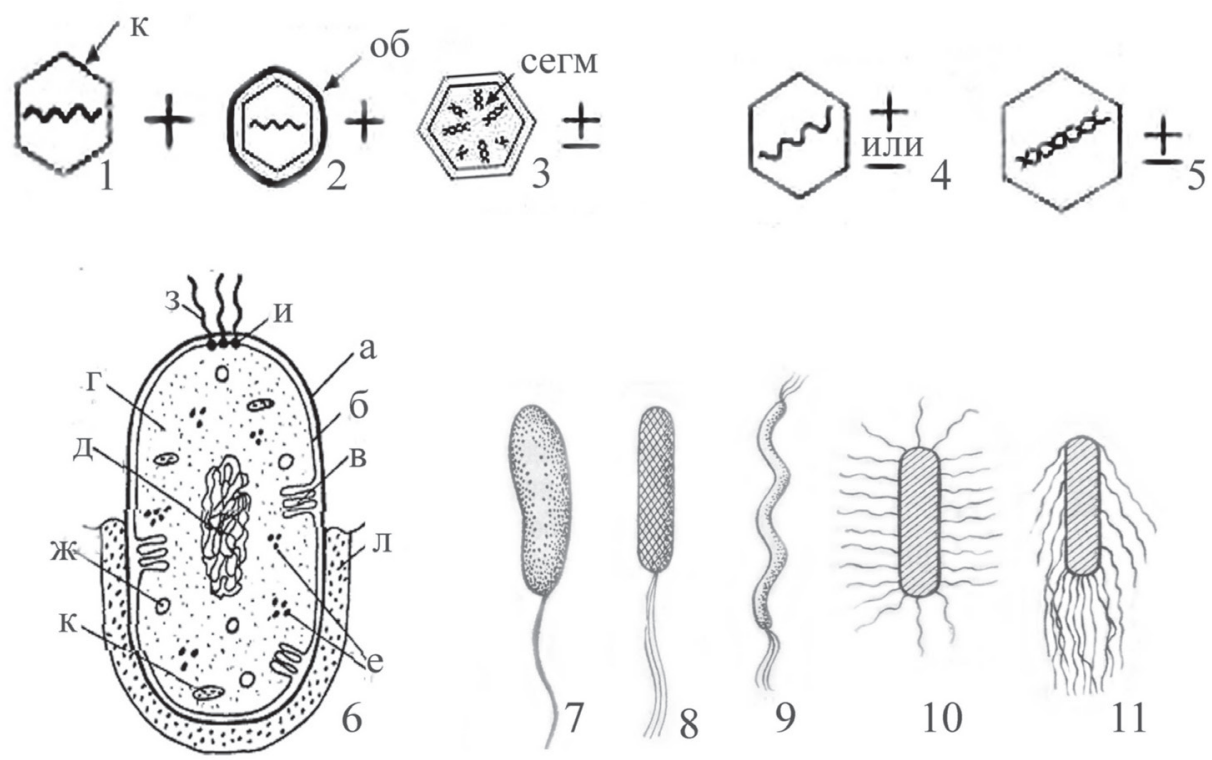

10

11

Рис. 14. Схема строения вирусов и бактерий: 1-5 - вирусы; 6-11 - бактерии:

1-3: схемы строения некоторых PHК-содержащих вирусов: 1 - Astrovirus; 2 - Calcivirus; 1 -2 - однонитчатый геном; 3 - Reоvirus (к - капсид, об - оболочка, сегм - от 10 до 12 сегментов двунитчатого генома);

4-5: схемы строения некоторых ДНК-содержащих вирусов: 4 - Parvovirus (однонитчатый геном); 5 - Adenovirus (двунитчатый геном) (1-5 по [61] с модификациями), (знаки + и - обозначают плюс и минус цепи, последние, прежде чем образовать вирусные белки, должны синтезировать плюс-цепь с помощью специального фермента);

6 - схема строения бактериальной клетки: а - клеточная стенка; 6 - цитоплазматическая мембрана; в - мезосомы; г цитоплазма; д - нуклеоид; е - рибосома; ж - запасные вещества; з - жгутики; и - базальные тела жгутиков; к - тилакоиды; л - капсула (по [91];

7-11: типы расположения жгутиков у бактерий: 7 - Vibrio; 8 - Pseudomonas; 9 - Spirillum; 10-1 1 - Proteus (по [19])

Вирусы являются самыми просто устроенными организмами из всех существующих на Земле форм жизни. Из-за мелких размеров (в среднем около 100 нм) их впервые удалось рассмотреть в 1930-е гг. после изобретения электронного микроскопа. Схема их строения представлена на рис. $14,1-5$. Вирусы состоят из нуклеиновой кислоты (генетического материала, необходимого для репликации новых вирусов) и белковой оболочки - капсида (от латинского слова капса - ящик).

Нуклеиновая кислота образует сердцевину вируса. Капсид окружает вирус, он состоит из субъединиц капсомеров, которые образуют структуры высокой степени симметрии, поэтому многие вирусы выглядят как правильные многоугольники, структуры кубической или сферической формы, либо смешанного типа симметрии. У некоторых вирусов имеется дополнительная липопротеидная оболочка, образованная из плазматической мембраны клетки хозяина (рис. 14, 2). Изредка имеются тонкие хвостовые фибриллы. Вирусы не имеют рибосом и почти не содержат никаких ферментов.

Вирусные геномы содержат от нескольких до 200 генов и могут быть представлены одноцепочечной (рис. 14, 1, 2) или двухцепочечной вирусной цепью РНК или ее сегментами (рис. 14,3 ), либо одноцепочечной (рис. 14, 4) или двухцепочечной (рис. 14, 5) вирусной ДНК.

При столь бедной морфологии нет базы для олигомеризации, но дупликация нитей РНК и ДНК, в некоторых случаях их сегментацию и наличие второй липопротеидной оболочки можно рассматривать как начальные проявления процессов полимеризации.

\section{Начальные процессы полимеризации у бактерий}

До сравнительно недавнего времени бактерии было принято относить к Prokaryota. И хотя сейчас это название рассматривают как устаревшее, оно, тем не менее, удобно при сопоставлении эукариотических организмов, обладающих оформленным ядром, и организмов, не имеющих такового. Точно так же ученые продолжают использовать термин «протисты» утерявший свой строго таксономический смысл.

Долгое время предметом биологической эволюции были только одноклеточные и многоклеточные животные и растения. Успехи микробиологии последних десятилетий сделали возможным изучение эволюционных изменений и на микробиологическом уровне. C.R. Woese [96] предложил схему трехдоменной классификации организмов. Он выделил домены бактерий (эубактерий), архей и эукариот, предположив их возможное происхождение от гипотетического общего предка LUCA (last universal common ancestor). Основанием для такого предположения служит наличие общей системы передачи наследственной информации с образованием РНК и белков и с ипользованием 20 универсальных аминокислот. Все же вероятно, что общий предок должен подразумеваться как предшествующий уровень организации, а не как единственный монофилетический предок. Поэтому Е. Кунин [24] обоснованно предложил модифицировать название как LUCAS "Last Universal Common Ancestor State - последнее универсальное предковое состояние (всего живого)". 
Поскольку и бактерии, и археи представляют собою одноклеточные микроорганизмы, не имеющие ядра, а также каких-либо мембранных органелл, а отличия между ними носят, в основном, биохимический характер, в данной статье можно ограничиться рассмотрением начальных процессов полимеризации клетки бактерий (рис. 14, 6-11). По сравнению с вирусами клетка у бактерий устроена более сложно. У бактерий имеются такие основные органеллы, как нуклеоид, цитоплазма, отвечающие за синтез белка рибосомы, цитоплазматическая мембрана, клеточная стенка, выполняющая функции защиты, фагоцитоза, регуляции осмотического давления и некоторые другие (рис. 14, 6). В цитоплазме бактерий могут находиться автономные кольцевые молекулы ДНК с меньшей молекулярной массой - плазмиды. К дополнительным органеллам относятся капсулы, жгутики и их базальные тела, мезосомы - производные цитоплазматической мембраны в виде мембран, пузырьков и трубочек, многие бактерии способны образовывать споры.

В бактериальной клетке имеются наборы органелл, представляющие различные системы организменного уровня, и можно говорить о полимеризации организменных систем в их организме. Кроме того, отдельные органеллы, такие как рибосомы или плазмиды, находятся в их клетке во множественном числе, то есть могут быть полимеризованными. К сожалению, данные об их количествах в разных группах бактерий нам не известны. Зато картина изменения числа жгутиков напоминает таковую у жгутиконосцев - для каждого из родов характерно их определенное число (рис. 14, 7-11), и можно определенно говорить об их полимеризации.

Увеличение числа любых из этих органелл и появление в их клетке нескольких систем органелл с определенными свойствами увеличивает возможности выживания бактерий и интенсификации функций как самих этих органелл, так и всей бактериальной клетки.

Возникшие позже эукариоты значительно крупнее бактерий: если в среднем величина бактерий несколько мкм (до 2000 нм в длину), то средняя величина эукариотической клетки 50000 нм (= 50 мкм в диаметре) и примерно в 1000 раз больше по объему. Для сравнения, средние размеры вирусов - 80100 нм, то есть еще на два-три порядка меньше бактерий. Поскольку увеличение размеров по А.В. Догелю [12] представляет собою третий способ полимеризации, этот последовательный ряд возрастания размеров наглядно иллюстрирует роль полимеризации при переходе на каждый новый уровень организации.

Эукариотическая клетка обладает более богатым набором органелл, включая диктиосомы аппарата Гольджи и митохондрии, и более сложной организацией. Все ее органеллы ограничены мембранами, не только ядро, благодаря наличию которого эукариоты и получили свое название. Сложная система ее внутренних мембран создает высокую степень компартментализации и дифференциации цитоплазмы, отсутствующую у бактериальной клетки, бо́льшую плотность и вязкость ее внутренней среды, затрудняющей передвижение макромолекул в отличие от их свободного перемещения в жидкой цитоплазме бактерий. Всё это приводит в обоих рассматриваемых случаях к глубоким различиям механизма транспортных систем [24]. Прокариотная и эукариотная клетки отличаются также по особенностям строения их рибосомальной РНК: три РНК у прокариот с константой седиментации $70 \mathrm{~S}$ и четыре РНК с константой седиментации $80 \mathrm{~S}$ у эукариот, что говорит о различии их массы и количества нуклеотидов. В данной статье не затрагиваются и не обсуждаются биохимические особенности и их механизмы, но более детально рассматривавший их Е. Кунин [24] пришел к выводу о «...пропасти между прокариотической и эукариотической клеточной организацией».

Все вышесказанное позволяет говорить о более высокой полимеризации организменных систем эукариотной клетки по сравнению с прокариотной клеткой бактерий, и даже о повышении массы и числа нуклеотидов в рибосомальной РНК эукариот. Увеличение числа структурных уровней представляет собою частный случай полимеризации.

\section{ПРОЦЕССЫ ПОЛИМЕРИЗАЦИИ И ОЛИГОМЕРИЗАЦИИ В ЭКОСИСТЕМАХ}

Поскольку в экосистемах присутствуют не только многоклеточные, но и одноклеточные и бактериальные организмы, здесь уместно рассмотреть некоторые свойства экосистем, попытаться проанализировать в свете закона В.А. Догеля.

Одно из классических определений экосистемы звучит следующим образом: «биологическая система, состоящая из сообщества живых организмов, среды их обитания и системы связей, осуществляющей обмен веществом и энергией между ними». Система связей определяет функционирование внутри экосистем потоков энергии, вещества и информации. (Способность активно, самостоятельно создавать и воспроизводить информацию и есть, по моему мнению, основное свойство живой материи, ее главное отличие от неживой, где информационные изменения происходят лишь в результате изменения воздействия внешних сил.) Поскольку системы функционирования экосистем чрезвычайно сложны и с трудом поддаются изучению, большинство экологических исследований ограничивается их структурным анализом. Основным структурным элементом экосистем является вид. Если процесс размножения отдельной особи является для нее именно процессом размножения, а не полимеризации, то для популяции этого вида и для всего этого вида в экосистеме увеличение числа особей можно считать процессом полимеризации, так же как и общее увеличение числа различных видов в биотопе.

Обособление в экосистемах отдельных подсистем экологических ниш - также может быть примером полимеризации внутри экосистемы, а в случае специализации этих ниш - примером дифференциации 
или олигомеризации. Интегрирующую роль в экосистемах играют потоки энергии.

Увеличение числа тех или иных компонентов внутри экосистем ведет к росту и общему повышению сложности всей системы.

\section{ЗАКЛЮЧЕНИЕ}

Как было показано выше на группах организмов разной степени сложности - от самых примитивных вирусов и более сложно устроенных бактерий до одноклеточных эукариот, - а также на таких сложных биологических системах, как экосистемы, открытый В.А. Догелем закон полимеризации/олигомеризации действует на всех этих уровнях, включая, разумеется, и уровень самых сложно устроенных многоклеточных эукариот, где проявления этого закона изучены наиболее полно и самим В.А. Догелем, и многими более поздними авторами. Он является универсальным законом развития всех живых структур и проявляется не только на организменном, но и на клеточном, и внутриядерном уровне (полимеризация геномов и их дифференциация, и даже дифференциация макронуклеуса - рис. 4,21$)$. Собственно говоря, дупликацию генов и геномов, которую Ohno [83] считает основой эволюции не только геномов, но и организмов, можно рассматривать как частный случай полимеризации.

При этом, как было рассмотрено ранее В.А. Догелем [11-15], а в данной статье продемонстрировано на более многочисленных примерах организмов различной степени сложности, олигомеризация может возникать лишь на базе предшествующей полимеризации. Так, у вирусов, являющихся самыми примитивными из ныне известных организмов, у которых можно найти лишь самые начальные стадии полимеризации, олигомеризация не известна.

Чем более продвинута группа в своем эволюционном развитии, тем более проявляются у нее процессы олигомеризации. В.А. Догелем было показано преобладание процессов полимеризации над процессами олигомеризации у одноклеточных эукариот по сравнению с многоклеточными эукариотами. Однако у такой сложной группы протистов, как фораминиферы, достигшей высокой степени организации, случаи олигомеризации многочисленны и чрезвычайно высока степень связанной с нею дифференциации и интеграции (см. выше). Сложнейшие разветвленные системы каналов, снабжающие цитоплазму многочисленных камер кислородом, сравнимы по своей функции с кровеносной системой Metazoa. Они демонстрируют своеобразный путь эволюции и как бы попытку вырваться за пределы одноклеточности.

Преобладание в разных группах процессов полиили ологомеризации характеризует качественный уровень развития каждой из них.

Изучение процессов полимеризации/олигомеризации разных групп организмов помогает определить вектор эволюционного развития группы и служит ключом к пониманию их филогении. Основанная с учетом этих закономерностей приведенная выше схема многокамерных классов фораминифер (рис. 12) иллюстрирует постепенные параллельные усложнения в каждом из них (увеличение числа камер, устьев, усложнение устьевых структур и интегрирующих структур раковин вплоть до появления системы каналов) и напоминает ряды таблицы Менделеева. Вдоль всех 4 рядов происходит постепенное увеличение сложности, так же как и в отдельных мѐньших ветвях внутри них. И хотя это повышение уровня организации здесь выражено не столь строго, как в химии, оно, тем не менее, закономерно и в значительной степени предсказуемо. На его основе было предсказано возможное существование нового рода фораминифер, который позже и был обнаружен (см. выше - рис. 13) [33, 34].

Некоторое сходство с таблицей Менделеева было замечено и в таблице классификации вирусов, в которой также остались незаполненные места, позволяющие предполагать существование еще не открытых вирусов ${ }^{5}$.

Подобные примеры показывают, что понятия полимеризации/олигомеризации носят системный характер, а построенные на их основании схемы обладают прогностической ценностью.

Полимеризация является необходимой предпосылкой при переходе на следующую, более высокую ступень организации, что можно проиллюстрировать на примере супермногокамерных фораминифер (см. выше). В таких высоко полимеризованных структурах при отсутствии или недостаточном развитии дальнейших процессов олигомеризованных и интегрирующих систем может произойти дезинтеграция отдельных частей, что, как показали Prigogine и Stengers [88], может привести к полной потере связей между ними, утрате равновесного состояния и даже к хаосу и гибели системы (в данном случае организма). Переход из разбалансированного состояния на новый уровень организации совершается благодаря развитию последующих процессов олигомеризации и связанных с ней дифференциации и интеграции, что ведет к сохранению целостности организма, повышению функциональной активности и конкурентоспособности, помогает его выживанию. Совершается переход на более сложный уровень организации обычно тогда, когда возможности предыдущего уровня оказываются исчерпанными.

Таким образом, процессы полимеризации/олигомеризации и связанных с ними дифференциации и интеграции являются магистральным путем эволюционных процессов, обеспечивая, наряду с законом Пригожина-Стингерс, механизм перехода на новый уровень организации. На первый взгляд, оба эти закона кажутся простыми и самоочевидными, в этом может быть одна из причин того, что открытие В.А. Догеля долгое время не привлекало достаточного внимания. И, может быть, именно в этом случае так верна поговорка: «Все гениальное - просто».

URL: http://schools.keldysh.ru/school1413/bio/vilegzh/str4.htm (Последняя дата доступа: 23.03.2016). 


\section{Литература}

\section{Список русскоязычной литературы}

1. Балушкин АВ. Процесс олигомеризации гипуральных элементов скелета хвостового плавника рыб на примере отряда Nodotheniformes. В кн.: Отчетная научная cecсия Зоологического института АН СССР по итогам работ 1973 г., 25-27 февр. 1974 г. Л.: Наука; 1974. С. 4-5.

2. Беклемишев ВН. Основы сравнительной анатомии беспозвоночных. М.: Наука; 1964.

3. Борхсениус НС. Процессы олигомеризации и полимеризации у Coccoidea (Homoptera, Insecta). Зоол журн. 1961;40(11):1597-610.

4. Воронова МН. О полиплоидии соматических ядер фораминиферы Cibicides lobatulus. Цитология. 1976;18(4):509-12.

5. Воронова МН. Ядерный дуализм гамонтов фораминиферы Cibicides lobatulus. Цитология.1978;20(8):859-67.

6. Воронова МН. Жизненный цикл фораминиферы Cibicides lobatulus (Диссертация). Л.: Изд-во ЛГУ; 1979.

7. Воронова МН, Михалевич ВИ. Современные представления о жизненных циклах фораминифер. Тр Зоол ин-та АН СССР. 1985; 129:48-66.

8. Гиляров МС. Биологический энциклопедический словарь М.: Советская энциклопедия; 1986.

9. Гинецинская ТА. Явление олигомеризации одноклеточных органов у личинок трематод. В кн.: Гельминты животных, человека и растений и борьба с ними. К 85-летию акад. Л.И. Скрябина, М.: Изд-во АН СССР; 1963. с. 204-7.

10. Городков КБ. Олигомеризация и стабилизация. В кн.: Скарлато АО, ред. Значение процессов полимеризации и олигомеризации в эволюции. Л.: Изд-во АН СССР; 1977. с. 9-12.

11. Догель ВА. Олигомеризация гомологичных органов как один из процессов эволюции животных организмов. Арх анат гистол эмбриол. 1936;15:101-14.

12. Догель ВА. Явление полимеризации и олигомеризации гомологичных органов в животном царстве и их эволюционное значение. Изв АН СССР Сер биол. 1947;4:471-86.

13. Догель ВА. Общая протистология. М.: Советская наука; 1951.

14. Догель ВА. Олигомеризация гомологичных органов. Л.: Изд ЛГУ; 1954.

15. Догель ВА, Полянский ЮИ, Хейсин ЕМ. Общая протозоология. М.; Л.: Изд-во АН СССР; 1962.

16. Житков ВС. Структурные особенности филломеров цветковых растений в связи с явлениями олигомеризации и полимеризации. В кн.: Скарлато АО, ред. Значение процессов полимеризации и олигомеризации в эволюции. Л.: Изд АН СССР; 1977. С. 82-7.

17. Захваткин АА. Сравнительная эмбриология низших беспозвоночных (источники и пути формирования индивидуального развития многоклеточных). М.: Советская наука, 1949.
18. Захваткин АА. Эволюция и морфологическое обоснование системы клещей. М.: Издво АН СССР; 1952. с. 53-66.

19. Зенкевич ЛА. Жизнь животных. Том 1. Беспозвоночные. М.: Просвещение; 1968.

20. Каратыгин ИВ. Значение полимеризации в происхождении и эволюции головневых грибов (порядок Ustilaginales). В кн.: Скарлато ОА, ред. Значение процессов полимеризации и олигомеризации в эволюции. Л.: Изд-во АН СССР; 1977. c. 70-2.

21. Карпов СА. Система протистов. Омск: Омск пед ин-т; 1990.

22. Карпов CA. Hemimastigophorea. Thaumatomonadina. В кн.: Пугачев ОН, ред. Руководство по зоологии. Часть 3. Protista: СПб., М.: Товарищество научных изданий КМК; 2011. c. $329-42,402-28$.

23. Корецкий ВМ. Избыточность как необходимая характеристика организации эволюционирующих систем. В кн.: Организация и эволюция живого (философские, историко-научные и теоретические аспекты проблемы), Л.: Наука; 1972. с. 170-8.

24. Кунин Е. Логика случая. О природе и происхождении биологической эволюции. М.: ЗАО Изд-во Центрполиграф; 2014.

25. Мамкаев ЮВ, Дробышева ИМ. О множественной закладке семенных сумок и их наконечников у бескишечной турбеллярии Convoluta convoluta (Abildgaard). Докл AH CCCP. 1971;196(6):1474-6.

26. Маслакова НИ. О полимеризации и олигомеризации в эволюции глоботрунканид. В кн.: IV научно-отчетная конференция геологического факультета Московского государственного универститеа (тезисы докладов). М.: МГУ; 1969. с. 157-8.

27. Мейен СВ. Проблемы направленности эволюции. В кн.: Итоги науки и техники: 3оология позвоночных. Проблемы теории эволюции. М.: ВИНИТИ; 1975. с. 66-117.

28. Мейен СВ. Олигомеризация и полимеризация в эволюции древнейших высших растений. В кн.: Скарлато ОА, ред. Значение процессов полимеризации и олигомеризации в эволюции. Л.: Изд-во АН СССР; 1977. с. 75-8.

29. Михалевич ВИ. Систематика и эволюция фораминифер в свете новых данных по их цитологии и ультраструктуре. Тр Зоол ин-та АН СССР. 1980;94:42-61.

30. Михалевич ВИ. Параллелизм и конвергенция в эволюции скелетов фораминифер. Тр Зоол ин-та АН СССР. 1981;107:19-41.

31. Михалевич ВИ. Донные фораминиферы шельфов тропической Атлантики. Л.: Наука; 1983.

32. Михалевич ВИ. Макросистема фораминифер (диссертация). Л.: Изд-во Зоол ин-та РAH; 1992.

33. Михалевич ВИ. Система и филогения фораминифер. Омск; СПб.: Изд-во Государственного педагогического университета; 1999. 
34. Михалевич ВИ. Фораминиферы. В кн.: Алимов АФ, ред. Основы зоологии. Ч 1. Protista. СПб.: Наука; 2000. С. 525-637.

35. Наумов АД, Боркин ЛЯ, Подлипаев СА. Принципы полимеризации и олигомеризации: процессы и системы. В кн.: Скарлато ОА, ред. Значение процессов полимеризации и олигомеризации в эволюции. Л.: Изд-во АН СССР 1977:5-9.

36. Осипов ДВ. Проблемы гетероморфизма ядер у одноклеточных организмов. Л.: Наука; 1981.

37. Петрушевская МГ. Процессы полимеризации и олигомеризации в эволюции радиолярий. В кн.: Скарлато ОА, ред. Значение процессов полимеризации и олигомеризации в эволюции. Л.: Изд-во АН СССР; 1977. с. 35-8.

38. Подлипаев СА, Наумов АД, Боркин ЛЯ. К определению понятий полимеризации и олигомеризации. Журн общ биол. 1974;35(1): 100-13.

39. Полянский ЮИ. О морфологических закономерностях эволюции простейших. Зоол журн. 1970;49(4):560-9.

40. Полянский ЮИ, Райков ИБ. Роль полиплоидии в эволюции простейших. Цитология 1960;(2):509-18.

41. Полянский ЮИ, Райков ИБ. Полимеризация и олигомеризация в эволюции простейших. Журн общ биол. 1977;38:325-35.

42. Полянский ЮИ, Райков ИБ. Полимеризация и олигомеризация в эволюции простейших. В кн.: Скарлато ОА., ред. Значение процессов полимеризации и олигомеризации в эволюции. Л.: Изд-во АН СССР; 1977. c. 29-32.

43. Райков ИБ. Новые данные о полиплоидных ядрах у простейших. В кн.: Полиплоидия и селекция. М.; Л.; 1965. с. 134-42.

44. Райков ИБ. Кариология простейших. Л.: Наука; 1967.

45. Райков ИБ. Ядро простейших. Морфология и эволюция. Л.: Наука; 1978.

46. Серавин ЛН. Макросистема жгутиконосцев. Тр Зоол ин-та АН СССР. 1980;94:4-22.

47. Серавин ЛН, Гудков АВ. Агамные слияния протистов и происхождение полового процесса. СПб.; Омск: Изд-во ОМ ГПУ; 1999.

48. Слепян ЭИ. Об олигомеризации мальпигиевых сосудов у галиц (Diptera, Itonididae). Тр Ленинградского общ-ва естествоиспытателей отдел зоол. 1957;73(4):43-5.

49. Субботина НН. Пути эволюции фораминифер. Л.: Изд-во ЛГУ; 1968.

50. Суханова КМ. Класс Euglenoidea. В кн.: Алимов АФ, ред. Основы зоологии. Часть 1. Protista. СПб.: Наука; 2000. с. 201-10.

51. Суханова КМ. Класс Opalinata. В кн.: Алимов АФ, ред. Основы зоологии. Часть 1 Protista. СПб.: Наука; 2000. с. 297-313.

52. Суханова КМ, Карпов СА. Класс Chrysophyceaea. В кн.: Алимов АФ, ред. Основы зоологии. Часть 1. Protista. СПб.: Наука; 2000. c. $258-64$.

53. Тахтаджан АЛ. Вопросы эволюционной морфологии растений. Л.: Изд-во ЛГУ; 1954.
54. Фролов АО. Класс Kinetoplastidea. В кн.: Алимов АФ, ред. Основы зоологии. Часть 1. Protista. СПб.: Наука; 2000. с. 211-57.

55. Фролов AO. Pelobiontida. В кн.: Пугачев $\mathrm{OH}$, ред. Руководство по зоологии. Protista. Часть 3. СПб., М.: Товарищество научных изданий КМК; 2011. с. 270-308.

56. Фурсенко АВ, Раузер-Черноусова ДМ. Простейшие. Подкласс Foraminifera. Фораминиферы. В кн.: Фурсенко АВ, Раузер-Черноусова ДМ, ред. Основы палеонтологии. М.: Изд-во АН СССР; 1959. с. 115-346.

57. Хохряков АП. Условия существования как причина поли- и олигомеризации у растений. В кн.: Скарлато ОА., ред. Значение процессов полимеризации и олигомеризации в эволюции. Л.: Изд-во АН СССР; 1977. с. 78-82.

58. Шарова ИХ. Зоология беспозвоночных. М.: ВЛАДОС; 2002.

59. Ширкина НИ. Морфология и жизненный цикл Haumatomonas lauterborni De Saedaleer (Mastigophora Diesing). В кн.: Фауна и биология пресноводных организмов. Л.: Наука; 1987. c. $87-107$.

\section{Общий список литературы/Reference List}

1. Balushkin AV. [The process of oligomerization of skeletal gipural elements of fish tail fin as exemplified with the order Nodotheniformes]. In: Otchentnaya Nauchnaya Sessiya Zoologicheskogo Instituta AN SSSR po Itogam Rabot 1973 G. Leningrad: Nauka; 1974. p. 4-5. (In Russ.)

2. Beklemishev VN. Osnovy Sravnitel'noy Anatomii Bespozvonochnykh. [Essentials of the Comparative Anatomy of Invertebrate]. Moscow: Nauka; 1964. (In Russ.)

3. Borkhsenius NS. [Processes of oligomerization and polymerization in Coccoidea (Homoptera, Insecta)]. Zoologicheskiy Zhurnal. 1961;40(11):1597-610. (In Russ.)

4. Voronova MN. [On the polyploidy of somatic nuclei in the foraminifer Cibicides lobatulus]. Tsytologiya. 1976;18(4):509-12. (In Russ.)

5. Voronova MN. [Nuclear dualism of the gamonts of the foraminifera Cibicides lobatulus]. Tsytologiya.1978;20(8):859-67. (In Russ.)

6. Voronova MN. Zhiznennyi Tsykl Foraminifery Cibicides lobatulus. [The Life Cycle of the Foraminifer Cibicides lobatulus]. (PhD Theses). Leningrad: LGU; 1979. (In Russ.)

7. Voronova MN, Mihalevich VI. [The current concepts of Foraminifera life cycles]. Trudy Zoologicheskogo Instituta AN SSSR. 1985;129:4866. (In Russ.)

8. Gilyarov MS. Biologicheskiy Entsyklopedicheskiy Slovar. [Biological Encyclopedic Dictionary]. Moscow: Sovetskaya Entsyklopediya; 1986. (In Russ.)

9. Ginetsinskaya TA. [The phenomenon of oligomerization of unicellular organs in trematode larvae]. In.: Gel'minty Zhivotnyh, Cheloveka i Rastenii i Bor'ba s Nimi. K 85-letiyu akad. LI Skryabina, Mjscow: Izdatelstvo AN SSSR; 1963. p. 204-7. (In Russ.)

10. Gorodkov KB. [Oligomerization and stabilization]. In: Skarlato AO, ed. Znacheniye Processov 
Polimerizatsii i Oligomerizatsii v Evoliutsii. Leningrad: Izdatelstvo AN SSSR; 1977. p. 9-12. (In Russ.)

11. Dogel VA. [Oligomerization of homologous organs as one of the processes of animal evolution]. Arkhiv Anatomii Gistologii i Embriologii. 1936;15:101-14. (In Russ.)

12. Dogel VA. [Oligomarization and polymerization of homologous organs in animal kingdom and the significance of these processes in organic evolution]. Izvestiya AN SSSR Ser Biol. 1947;4:471-86. (In Russ.)

13. Dogel VA. Obshaya Protistologiya [General Protistology]. Moscow: Sovetskaya Nauka; 1951. (In Russ.)

14. Dogel VA. Oligomerizatsiya Gomologichnykh Organov. [Oligomerization of Homologous Organs]. Leningrad: Izdatelstvo LGU; 1954. (In Russ.)

15. Dogel VA, Polyanskiy YuI, Heisin EM. Obschaya Protozoologiya. [General Protozoology]. Moscow; Leningrad: Izdatelstvo AN SSSR; 1962. (In Russ.)

16. Zhitkov VS. [Structural features of flowering plants fillomers with regard to polymerization and oligomerization phenomena]. In: Skarlato AO, ed. Znacheniye Processov Polimerizatsii i oligomerizatsii v Evoliutsii. Leningrad: Izdatelstvo AN SSSR; 1977. p. 82-7. (In Russ.)

17. Zakhvatkin AA. Sravnitel'naya Embriologiya Nizshikh Bespozvonochnyh (Istochniki i Puti Formirovaniya Individual'nogo Razvitiya Mnogokletochnykh). [Comparative Embryology of the Lower Invertebrates (Sources and the Ways of Formation of the Individual Development of Multicellular Organisms]. Moscow: Sovetskaya Nauka; 1949. (In Russ.)

18. Zakhvatkin AA. Evolyuciya i Morfologicheskoye Obosnovaniye Sistemy Kleschey. [Evolution and the Morphological Basis of Tick System]. Moscow: Izdatelstvo AN SSSR; 1952. p. 53-66. (In Russ.)

19. Zenkevich LA. Zhizn' Zhivotnykh. Tom 1. Bespozvonochnye. [Animals' Life. Vol. 1. Invertebrates]. Moscow: Prosvescheniye; 1968. (In Russ.)

20. Karatygin IV. [The significance of polymerization in the origin and evolution of the ustilago (order Ustilaginales)]. Skarlato AO, ed. Znacheniye Processov Polimerizatsii i Oligomerizatsii v Evoliutsii. Leningrad: Izdatelstvo AN SSSR; 1977. p. 70-2. (In Russ.)

21. Karpov SA. Sistema Protistov. [The System of Protists]. Omsk: Omskiy Pedagogicheskiy Institut; 1990. (In Russ.)

22. Karpov SA. Hemimastigophorea. Thaumatomonadina. In: Pugachev ON, ed. Rukovodstvo po Zoologii. Chast 3. Protista. [Manual of Zoology. Pt. 3. Protista]. SaintPetersburg and Moscow: Tovarischestvo Nauchnykh Izdaniy KMK; 2011. P. 329-42, 40228. (In Russ.)

23. Koretskiy VM. [Superfluity as a necessary character of evolving systems]. In: Organizatsiya i Evoliutsiya Zhivogo (Filosofskiye, Istoriko-Nauchnye i Teoreticheskiye Aspekty Problemy). Leningrad: Nauka; 1972. p. 170-8. (In Russ.)
24. Koonin E. Logika Sluchaya. O Prirode i Proiskhozhdenii Biologicheskoy Evoliutsii. [The Logic of Chance. The Nature and Origin of Biological Evolution]. Moscow: ZAO Izdatel'stvo Centrpoligraf; 2014. (In Russ.)

25. Mamkayev YuV, Drobysheva IM. [On the multiple laying of the spermatic bags and their tips in the acoela turbellaria Convoluta convoluta (Abildgaard)]. Doklady AN SSSR. 1971;96(6):1474-6. (In Russ.)

26. Maslakova NI. [On the polymerization and oligomerization in the evolution of globotruncanid]. In: IV Nauchno-Otchetnaya Konferentsiya Geologicheskogo Fakulteta Moskovskogo Gosudarstvennogo Universiteta (Tezisy Dokladov). Moscow: MGU; 1969. p. 157-8. (In Russ.)

27. Meyen SV. [Problems of the evolutionary trends]. In: Itogi Nauki i Tekhniki: Zoologiya Pozvonochnykh. Problemy Teorii Evoliutsii. Moscow: VINITI; 1975. p. 66-117.

28. Meyen SV. [Oligomerization and polymerization in the evolution of the most ancient higher plants]. In: Skarlato AO, ed. Znacheniye Processov Polimerizatsii i Oligomerizatsii v Evoliutsii. Leningrad: Izdatelstvo AN SSSR; 1977. p. 75-8. (In Russ.)

29. Mikhalevich VI. [Systematics and evolution of the Foraminifera in view of new data on their cytology and ultrastructure]. Trudy Zoologicheskogo Instituta AN SSSR.1980;94:42-61. (In Russ.)

30. Mikhalevich VI. [Parallelism and convergence in the evolution of the foraminiferal skeleton]. Trudy Zoologicheskogo Instituta AN SSSR. 1981;107:19-41. (In Russ.)

31. Mikhalevich VI. Donnye Foraminifery Shel'fov Tropicheskoy Atlantiki. [The Bottom Foraminifera of Tropical Atlantic Shelfs]. Leningrad: Nauka; 1983. (In Russ.)

32. Mikhalevich VI. Makrosistema foraminifer. [The Macrosystem of Foraminifera (PhD Theses]. Saint-Petersburg: Zoologicheskiy Institut RAN; 1992. (In Russ.)

33. Mikhalevich VI. Sistema i Filogeniya Foraminifer. [The System and Phylogeny of Foraminifera]. Omsk and Saint Peterburg: Izdatelstvo Gosudarstvennogo Pedagogicheskogo Universiteta; 1999. (In Russ.)

34. Mikhalevich VI. Foraminifera. In: Alimov AF, ed. Osnovy Zoologii. Chast 1. Protista. [Foundations of Zoology. Pt. 1. Protista]. Saint Petersburg: Nauka; 2000). p. 525-637. (In Russ.)

35. Naumov AD, Borkin LYa, Podlipaev SA. [Principles of polymerization: processes and systems]. In: Skarlato AO, ed. Znacheniye Processov Polimerizatsii i Oligomerizatsii v Evoliutsii. Leningrad: Izdatelstvo AN SSSR; 1977. p. 5-9. (In Russ.)

36. Osipov DV. Problemy Geteromorfizma Yader u Odnokletochnyh Organizmov. [Problems of Nuclear Heteromorphism in Unicellular Organisms]. Leningrad: Nauka; 1981. (In Russ.)

37. Petrushevskaya MG. [Processes of polymerization and oligomerization in Radiolaria]. In: Skarlato AO, ed. Znacheniye Processov Polimerizatsii i Oligomerizatsii v Evoliutsii. Leningrad: Izdatelstvo AN SSSR; 1977. p. 35-8. (In Russ.) 
38. Podlipayev SA, Naumov AD, Borkin LYa. [On the definition of the notions of polymerization and oligomerization]. Zhurnal Obshey Biologii. 1974;35(1):100-13. (In Russ.)

39. Polyanskiy YuI. 1970. [On the morphological regularities of protistan evolution]. Zoologicheskiy Zhurnal. 1970;49(4):560-9. (In Russ.)

40. Polyanskiy YuI, Raykov IB. [Role of polyploidy in Protistan evolution]. Tsytologiya. 1960;2:509-18. (In Russ.)

41. Polyanskiy YuI, Raykov IB. [Polymerization and oligomerization in evolution of protists]. Zhurnal Obshey Biologii. 1977;38:325-35. (In Russ.)

42. Polyanskiy YuI, Raikov IB. [Polymerization and oligomerization in evolution of protists]. In Znacheniye Processov Polimerizatsii i Oligomerizatsii v Evoliutsii. Leningrad: Izdatelstvo AN SSSR; 1977. p. 29-32. (In Russ.)

43. Raykov IB. [New data on polyploidy of nuclei in Protista]. In: Poliploidiya i Selektsiya (Trudy. Soveshaniya, 1963). Moscow and Leningrad; 1965. p. 134-42. (In Russ.)

44. Raykov IB. Kariologiya Prosteishikh. [Karyology of Protista]. Leningrad: Nauka; 1967. (In Russ.)

45. Raykov IB. Yadro Prosteishikh. Morfologiya i Evoliutsiya. [The Nucleus of Protozoans. Morphology and Evolution]. Leningrad: Nauka; 1978. (In Russ.)

46. Seravin LN. Makrosistema Zhgutikonostsev. [Macrosystem of Mastigophora]. Trudy Zoologicheskogo Instituta AN SSSR. 1980;94:4-22. (In Russ.)

47. Seravin LN, Gudkov AV. Agamnye Sliyaniya Protistov i Proiskhozhdeniye Polovogo Protsessa. [Agamic Fusions in Protists and the Origin of the Sexual Process]. Saint-Ptersburg and Omsk: Izdatelstvo OM GPU; 1999. (In Russ.)

48. Slepyan EI. [On oligomerization of the Malpighian tubes in midges (Diptera, Itonididae)]. Trudy Leningradskogo Obshestva Yestestvoispytateley Otdel Zoologii. 1957;73(4): 43-5. (In Russ.)

49. Subbotina NN. Puti Evoliutsii Foraminifer. [The Pathways of Evolution of Foraminifera]. Leningrad: Izdatelstvo Leningradskogo Gosudarstvennogo Universiteta; 1968. (In Russ.)

50. Sukhanova KM. [The class Euglenoidea]. In: Alimov AF, ed. Osnovy Zoologii. Chast 1. Protista. [Foundations of Zoology. Pt. 1. Protista]. Saint-Petersburg: Nauka; 2000. p. 201-10. (In Russ.)

51. Suhanova KM. [The class Opalinata]. In: A1imov AF, ed. Osnovy Zoologii. Chast 1. Protista. [Foundations of Zoology. Pt. 1. Protista]. Saint-Petersburg: Nauka; 2000. p. 297-313. (In Russ.)

52. Sukhanova KM, Karpov SA. [The class Chrysophyceaea]. In: Alimov AF, ed. Osnovy Zoologii. Chast 1. Protista. [Foundations of $\mathrm{Zo}-$ ology. Pt. 1. Protista]. Saint-Petersburg: Nauka; 2000. p. 258-64. (In Russ.)

53. Takhtadjan AL. Voprosy Evolyutsionnoy Morfologii Rastenii. [Problems of the Evolutionary Morphology of Plants]. Leningrad: Izdatelstvo Lenigradskogo Gosudarstvennogo Universiteta; 1954. (In Russ.)
54. Frolov AO. [The class Kinetoplastidea]. In: Alimov AF, ed. Osnovy Zoologii. Chast 1. Protista. [Foundations of Zoology. Pt. 1. Protista]. Saint-Petersburg: Nauka; 2000. p. 211-57. (In Russ.)

55. Frolov AO. [Pelobiontida]. In: Pugachev ON, ed. Rukovodstvo po Zoologii. Chast 3. Protista. [Manual of Zoology. Pt. 3. Protista]. Saint-Petersburg and Moscow: Tovarischestvo Nauchnykh Izdaniy KMK; 2011. p. 270-308. (In Russ.)

56. Fursenko AV, Rauzer-Chernousova DM. Prosteishiye. Podklass Foraminifera. Foraminifery. In.: Fursenko AV, Rauzer-Chernousova DM, eds. Osnovy Paleontologii. Moscow: Izdatelstvo AN SSSR; 1959. p. 115-346. (In Russ.)

57. Khokhriakov AP. [Living conditions as the cause of poly- and oligomerization in plants]. In: Skarlato AO, ed. Znacheniye Processov Polimerizatsii i Oligomerizatsii v Evoliutsii. Leningrad: Izdatelstvo AN SSSR; 1977. p. 78-82. (In Russ.)

58. Sharova IH. Zoologiya Bespozvonochnykh. [Zoology of Invertebrates]. Moscow: VLADOS; 2002. (In Russ.)

59. Shirkina NI. [Morphology and life cycles of Haumatomonas lauterborni DeSaedaleer (Mastigophora Diesing)]. In: Fauna i Biologiya Presnovodnyh Organizmov. Leningrad; Nauka. 1987. p. 87-107. (In Russ.)

60. Dogiel VA. Polymerization als ein Prinzip der progressiven Entwicklung bei Protozoa. Biol. Zbl. 1929;49(8):451-69.

61. Gelderblom HR. Structure and Classification of Viruses. In: Baron S, ed. Medical Microbiology. 4th edition. Galveston (TX): University of Texas Medical Branch at Galveston Press; 1996. URL: http://www.ncbi.nlm.nih.gov/books/NBK8174/.

62. Benson RN. Recent Radiolaria from the Gulf of California. (Ph.D. Thesis), University of Minnesota; 1966

63. Brady HB. Report on the Foraminifera Dredged by H.M.S. Challenger, During the years 1873-1876. In: Report on the Scientific Results of the Voyage of the H.M.S. Challenger during the years 1873-1876. Zoology. 1884

64. Cachon J, Cachon M. Le système axopodial des Radiolaires Sphaerodiés I. Centroaxoplastidiés. Arch Protistenk. 1972;114:51-64.

65. Cleve PT. Examination of Diatoms found on the surface of the Sea of Java. Bihang till Kongliga Svenska Vetenskaps-Akademiens Handlingar. 1873;1(11):1-13.

66. Ehrenberg CG. Neue Untersuchungen über das kleinste Leben als geologisches Moment. Bericht über die zur Bekanntmachung geeigneten Verhandlungen der Königlich-Preussischen Akademie der Wissenschaften zu Berlin. 1845:53-87.

67. Foissner W, Blatterer H, Foissner I. The Hemimastigophora (Hemimastix amphikineta nov. gen., nov. spec.), a new protistan phylum from Gondwanian soils. Eur J Protistol. 1988;23:361-83.

68. Frenzel J. Untersuchungen uber die Mikroskopische Fauna Aegentiniens Erster Teil: Die Protozoen. I und II. Abteilung: Die Rhizopoden und Helioamoben. Stuttgart: Verlag von Erwin Nagele; 1897.

69. Grell KG. Protozoologie. Berlin, Gottingen. Heidelberg: Springer-Verlag; 1956. 
70. Gruber A. Studien uber Amoeben. Zeit Wiss Zool. 1884;41:185-225.

71. Haynes JR. Foraminifera. New York: Wiley and Sons; 1981.

72. Haeckel E. Report on Radiolaria Collected by the H.M.S. Challenger During the Years 18731876. In: Thompson CW, Murray J., eds. Report on the Scientific Results of the Voyage of the H.M.S. Challenger, Zoology, London: 1887; XVIII.

73. Hottinger L. Illustrated Glossary of Terms used in Foraminiferal Research. In: Notebooks on Geology; 2006 (Pt 2): 126 p. URL: http://paleopolis. rediris.es/cg/uk index.html MO2 pdf 1-4.

74. Klebs G. Flagellatenstudien.Teil I. Z Wiss Zool. 1893;55:265-351.

75. Kozlov AP. Evolution by Tumor Neofunctionaliztion: The role of Tumors in the Origin of New Cell Types, Tissues and Organs. Amsterdam, Boston, Heidelberg, London, New York, Oxford, Paris, San Diego, San Francisco, Singapore, Sydney, Tokyo: Academic Press/ Elsevier, 2014.

76. Livingstone I. Protista. Greely. Canada. In: Biodidac, 1996. URL: Creative Commons Attribution-NonCommercial 4.0 International License. http://biodidac.bio.uottawa.ca/info/ regles.htm

77. Loeblich AR Jr, Tappan H. Foraminiferal Genera and their Classification. New York: Los Angeles Van Nostraand Comp; 1987 (Vol. 1, 2).

78. Mikhalevich VI. A new classification of the class Astrorhizata (Foraminifera). Zoosystematica Rossica. 1995;(2):161-74.

79. Mikhalevich VI. On the heterogeneity of the former Textulariina (Foraminifera). In: Bubik M, Kaminski MA, eds. Proceedings of the Sixth International Workshop on Agglutinated Foraminifera 2004. Grzybowski Foundation. 2004. Spec. Publ. 8. p. 317-49.

80. Mikhalevich VI. Polymerization and oligomerization in foraminiferal evolution. Stud Geol Poland. 2005;24:117-41.

81. Mikhalevich VI. General evolutionary regularities of organic and social life. In: Pontarotti $\mathrm{P}$, ed. Evolutionary Biology from Concept to Application. Part I. Modelization of Evolution. Berlin Heidelberg; Springer-Verlag; 2008. p. 73-94

82. Mikhalevich VI. Post-Cambrian Testate Foraminifera as a System in its Evolution. New York, Nova Science Publishers; 2013.

83. Ohno S. Evolution by Gene Duplication. Vienna: Springer; 1970.

84. Pawlowski J. Introduction to the molecular systematics of foraminifera. Micropaleontology. 2000;46(suppl 1):1-12.
85. Pawlowski J, Swiderski Z, Lee J. Observations on the ultrustructure and reproduction of Trochammina sp. (Foraminiferida). In: Kaminski MA, Geroch S, Gasinski MA, eds. Proceedings of the Fourth International Workshop on Agglutinated Foraminifera. Kraków Poland, Sept. 12-19, 1993. Grzybowski Foundation. 1995; Spec Publ 3:233-7.

86. Pawlowski J, Bolivar I, Fahrni J, Vargas C, Gouy M, Zaninetti L. Extreme differences in rates of molecular evolution of Foraminifera revealed by comparison of ribosomal DNA sequences and the fossil record. Mol Biol Evol. 1997;14(5):498-505.

87. Pawlowski J, Holzmann M, Tyszka J. New supraordial classification of Foraminifera: molecules meet morphology. Marine Micropaleontol. 2013;100:1-10.

88. Prigogine I, Stengers I. Order out of Chaos. London: Heinemann; 1984.

89. Rigaud S, Martini R, Rettori R. Taxonomy and phylogeny of Trocholinidae (Involutinina). J Foram Res. 2013;43:317-39.

90. Schlagentweit F, Rigaud S, Wilmsen M. Insight from exceptionally preserved Cenomanian trocholinids (benthic foraminifera) of Northern Cantabria, Spain. Facies. 2015;61(416):1-27.

91. Schlegel HG. Allgemeine Mikrobiologie. Stuttgart: George Thieme Verlag; 1969.

92. Shewiakoff W. Monographie die Acantharia des Golfes von Neapel. Roma: G. Baedi; Berlin: R. Friedlandwe und Sohn; 1926.

93. Skuja H. Beitrag zur algenflora lettlands II. Acta Horti Botanici Universitatis Latviensis. 1939;11/12:41-169.

94. Skuja H. Taxonomische und Biologische Studien das Phytoplankton Schwdischer Binnengewasser. Uppsala: Nova Acts Regiae Societatis Scientiarum Uppsaliensis, $4^{\text {th }}$ series. 1956; 16.

95. Stokes AC. A preliminary contribution toward a history of the fresh-water infusoria of the United States. J Trenton Nat Hist Soc. 1888;1: 73-319.

96. Woese CR. A new biology for a new century. Microbiol Mol Biol Rev. 2004;68:173-86.

97. Yubuki N, Leander BS. Ultrastructure and molecular phylogeny of Stephanopogon minuta: an enigmatic microeukaryote from marine interstitial environments. Europ Journ Protistology. 2008;44(4):241-53.

98. Zech L. Zytochemische Messungen an den Zellkernen der Foraminiferen Patellina corrugata und Rotaliella heterocariotica. Arch Protistenkd. 1964;107:295-330.

99. Zenkevitch LA. Evolution des structures morphologiques ches les animaux. XII Congr Int Zool. C.R. Paris. 1949:432-7. 